\title{
Discoloration of Dental Cements and Composites in a Sulfide Solution
}

\author{
Akiyoshi SUGAWARA ${ }^{1}$, Joseph M. ANTONUCCI ${ }^{2}$, George \\ C. PAFFENBARGER ${ }^{3}$ and Minoru NISHIYAMA ${ }^{1}$
}

(Received 13 September and accepted 30 October 1990) metal, color analysis

\begin{abstract}
In an early study the discoloration of certain hardened silicate cements, after exposure to an atmosphere of hydrogen sulfide $\left(\mathrm{H}_{2} \mathrm{~S}\right)$ for $24 \mathrm{~h}$ at room temperature, was ascribed to the formation of dark-colored sulfides of base metal impurities (Paffenbarger et al. JADA 25,32,1938). A recent study noted that, in general, silicate and glass ionomer cements were more prone to color shifts than composites after exposure to $\mathrm{H}_{2} \mathrm{~S}$ for 9 weeks (Sugawara, $\mathrm{Ph}$. D. Thesis, Nihon Univ.). The aim of the present study was to devise a simple, aqueous sulfide exposure test for esthetic restorative materials. The general procedure was to expose specimen disks to a $0.1 \%(\mathrm{w} / \mathrm{v})$ sodium sulfide solution, adjusted to $\mathrm{pH} 9$, for $1-7$ days at $37^{\circ}$ or $55^{\circ} \mathrm{C}$. The $55^{\circ} \mathrm{C}-\mathrm{Na}_{2} \mathrm{~S}$ exposure was designed as an accelerated test. Materials studied included: 1 silicate and 2 silicophosphate cements of known lead content, a glass ionomer cement (FIIF), several commercial composites and an experimental, hydrophilic composite. Known amounts of base metal contaminants in the form of appropriate salt solutions were added to the liquid components of FIIF and the composites. Specimens exposed to distilled water under the same conditions served as controls. Exposure to the aqueous sulfide medium resulted in the following ranking in order of decreasing discoloration: Glass ionomer cement $>$ silicophosphate cement $>$ silicate cement $>$ hydrophilic composite $>$ hydrophobic composite. Generally, the results of the aq. $\mathrm{Na}_{2} \mathrm{~S}$ test paralleled those obtained with $\mathrm{H}_{2} \mathrm{~S}$. The degree of discoloration is dependent on a number of factors: the nature, concentration and leachability of the metal impurities, and the hydro-

1 菅原明喜, 西山 實：Department of Dental Materials, Nihon University School of Dentistry Tokyo, JAPAN.

2 Dental and Medical Materials Group, Polymers Division, National Institute of Standards and Technology, Gaithersburg, MD 20899 USA.

3 American Dental Association, Paffenbarger Research Center, National Institute of Standards and Technology, Gaithersburg, MD 20899 USA.

To whom all correspondence should be addressed: Dr. Akiyoshi Sugawara, Department of Dental Materials, Nihon University School of Dentistry, 1-8-13 Kanda-Surugadai, Chiyoda-ku, Tokyo 101, JAPAN

The concept for this research originated with the late Dr. George C. Paffenbarger. The coauthors dedicate this paper to his memory for his inspirational leadership in fostering dental research and his many contributions to the science of dentistry.
\end{abstract}


philicity and permeability to sulfide of the esthetic restoratives.

\section{Introduction}

Laboratory tests of discoloration of dental materials in sulfide environments have been employed for many decades. An early example involved the degree of blackening of amalgams in a $1.4 \%$ solution of potassium sulfide ${ }^{[1]}$. A similar test employing a hydrogen sulfide atmosphere was conducted on gold alloys ${ }^{[2]}$ and silicate cements ${ }^{[3]}$. A comparison of the darkening of these silicate cements in the hydrogen sulfide atmosphere using spectrochemical analysis suggested that the darkening was caused by base metal contaminants which formed dark-colored sulfides $^{[3]}$. Because of intraoral putrefaction of sulfur-bearing proteins in many common foods, there is a strong probability that esthetic restorations contaminated with base metals also would eventually form dark-colored sulfides. Specifications issued by the British Standards Institution have restricted the lead content to not more than $40 \mathrm{ppm}$ in some cements ${ }^{[4]}$. However, this limitation of lead content was presumably for health reasons rather than concern for the potential clinical discoloration of restorations. The preparation of test specimens with these specifications $^{[4]}$ and their lead content, as determined by recognized analytical methods of adequate sensitivity, are comparatively elaborate. Consequently, it was felt that a simple exposure test would be adequate for demonstrating the presence not only of lead, but also of other unwanted base metals producing dark-colored sulfides.

Preliminary work at Nihon University in Japan produced evidence of sulfide discoloration of some dental composites and cements ${ }^{[5]}$. Similar work was continued in the present investigation, which examined a commercial glass ionomer cement, a silicate cement, two silicophosphate cements, several commercial composites, and an experimental hydrophilic composite.

\section{Materials and Methods}

The materials used in this study are listed in Tables 1-3 with their names, codes or acronyms and sources. The dental materials (Table 2) were refrigerated when not in use, but were allowed to reach room temperature prior to mixing. All specimens were prepared in air of $50 \pm 10 \%$ relative humidity at $23^{\circ} \mathrm{C}$.

\section{I . Preparation of $0.1 \%$ Sodium Sulfide Solution}

A $0.1 \% \mathrm{w} / \mathrm{v} \mathrm{Na}_{2} \mathrm{~S}$ solution was prepared by dissolving $2.961 \mathrm{~g}$ of sodium sulfide, $\mathrm{Na}_{2} \mathrm{~S} \cdot 9 \mathrm{H}_{2} \mathrm{O}$, in $1000 \mathrm{ml}$ of distilled water. A small amount of glacial acetic acid (about $0.5 \mathrm{ml}$ ) was added to adjust the $\mathrm{pH}$ to $9^{[6]}$. This $\mathrm{pH}$ was selected so that the concentrations of sulfide ion, $\mathrm{S}^{2-}$, and hydrosulfide ion $\left(\mathrm{SH}^{-}\right)$were relatively high compared to that of $\mathrm{H}_{2} \mathrm{~S}^{[6]}$. Also interference in the formation of metallic sulfides by hydroxyl ions $\left(\mathrm{OH}^{-}\right)$was considered to be largely insignificant at this $\mathrm{pH}$.

\section{Preparation of Base Metal Salt Solutions}


Various solutions containing known amounts (w/v) of the metal salts shown in Table 3 were prepared for introducing base metal contaminants into the glass ionomer cement and composite specimens (Tables 4 and 5, respectively).

\section{Specimen Preparation}

A. Contaminated Glass Ionomer Specimens

Introduction of known amounts of various base metal salts (Table 3) into the glass ionomer cement, FIIF (Table 2), was accomplished with the solutions shown in Table 4. For example, to introduce $40 \mathrm{ppm}$ of $\mathrm{Pb}$ into the FIIF specimen (Table 2), the following procedure was used: $263.1 \mathrm{mg}$ of FII (liquid component of the FIIF glass ionomer cement) was added to $70.2 \mathrm{mg}$ of solution A (Table 4) and mixed for $30 \mathrm{~s}$. The resulting liquid was then mixed for $1 \mathrm{~min}$ with $666.6 \mathrm{mg}$ of the glass ionomer cement powder using a powder/liquid ( $\mathrm{p} / \mathrm{L}$ ratio) of 2 . This mixed paste was then divided into halves and each half inserted into separate Teflon molds sandwiched between polyethylene sheets. The series of filled molds was hand-pressed between two glass plates (Fig. 1). The tapered disk-shaped specimens were set aside and allowed to harden at $23^{\circ} \mathrm{C}$ for $30 \mathrm{~min}$ (measured from the start of mixing), after which they were carefully removed from the molds without contamination by handling. Gentle flexing of the mold and the use of polyethylene gloves were effective in preventing unwanted contamination of the specimens during removal. The flash was trimmed away with a knife. Control and uncontaminated specimens were prepared similarly.

\section{B. Silicophosphate and Silicate Cement Specimens}

The three unidentified commercial cements, SP-I, SP-II, and S, provided by the Laboratory of the Government Chemists, U. K. (Table 2) contained known amounts of lead. Specimens were prepared using a $\mathrm{p} / \mathrm{L}$ ratio of 2.

\section{Composite Specimens}

The preparation of the contaminated composite specimens was accomplished using the identified dental composite materials (Table 2) and solutions of type I, II or III (Table 5). A preliminary screening investigation utilized thin specimens (thickness $=0.28-0.50 \mathrm{~mm}$ ) and solutions of types I and II. For example, a known amount of solution II-b (Table 5) was mixed with a known amount of each paste of a paste/paste commercial composite (Table 2) to obtain a final composite specimen with a given concentration of base metal in ppm. These thin specimens were prepared by mixing equal portions of each paste according to the recommendations of the manufacturers. The resulting paste was pressed between microscope slides $(77 \mathrm{~mm} \times 25 \mathrm{~mm})$ crossed at right angles. Thirty minutes after the start of mixing, the microscope slides were carefully separated and the thin specimens removed with a knife.

Thicker $(1.5 \mathrm{~mm})$ composite disks were prepared in a similar manner using larger Teflon molds (Fig. 1). Solutions IIa and IIb (Table 5) were used to introduce known amounts of $\mathrm{Pb}$ and $\mathrm{Cu}$ into specimens derived from composite $\mathrm{R}$ (Table 2) using the paste/paste technique described for the thin composite specimens. 
To study the role of the degree of hydrophilicity (i.e. water sorption) of a composite on the diffusion of $\mathrm{S}^{2-}$, an experimental, hydrophilic, powder-liquid composite formulation (HC) was prepared ${ }^{[7,8]}$. Metal contamination was obtained by adding known amounts of solution III (0.25\% LCB in BIS-GMA/HEMA: 3/1) to given amounts of the liquid component of $\mathrm{HC}$; the resulting liquid was then mixed with the silanized glass powder coated with benzoyl peroxide (BPO) using a $\mathrm{p} / \mathrm{L}$ ratio of 2 . Polymerization of the resulting paste was accomplished using a color stable initiator system consisting of BPO, ascorbic acid (AA 0.4\%) and ascorbyl palmitate (AP 0.4\% $)^{[9]}$. The AA and AP were dissolved in the liquid monomer system.

\section{Controls}

In addition to the preparation of control specimens containing base metal salts, which were exposed to distilled water rather than the $\mathrm{Na}_{2} \mathrm{~S}$ solution, other control specimens without metal contaminants also were prepared and exposed to both the distilled water and the $\mathrm{Na}_{2} \mathrm{~S}$ solution.

\section{General Procedure for Exposure of Specimens to $\mathrm{Na}_{2} \mathrm{~S}$ Solution}

Immediately after the 30-min hardening period, the various specimens derived from the dental materials listed in Table 2 were immersed in $5 \mathrm{ml}$ of $0.1 \% \mathrm{Na}_{2} \mathrm{~S}$ contained in vials sealed with Teflon-lined screw caps. As controls, similar specimens were immersed in $5 \mathrm{ml}$ of distilled water. All the materials were tested at $55^{\circ}$ $\mathrm{C}$ for the times specified in Figs. 2-6. Similar experiments were performed at $37^{\circ} \mathrm{C}$.

In addition to the silicophosphate and silicate cements (SP-1. SP-2, and S) which were known to contain significant amounts of $\mathrm{Pb}$ (Table 2), previous work had also demonstrated the presence of heavy metal contaminants in many of the other materials investigated in this study ${ }^{[5]}$. Therefore, specimens were prepared without addition of heavy metal salts in order to study their behavior after immersion in the $\mathrm{Na}_{2} \mathrm{~S}$ solution.

After the indicated exposure period (e.g. 1-7 days) the specimens were removed from their aqueous environment, dried with a cellulose towel and subjected to visual examination using as a white background a circle of filter paper and illumination provided by laboratory fluorescent lighting. The relative degree of discoloration was assessed by comparison of the appearance of the sulfide-exposed specimen with that of the corresponding control specimen, which was exposed only to distilled water.

\section{Measurement of Color Difference}

The colors of these specimens were measured using a dental color analyzer (Dental Color Analyzer N-S 100, J. Morita Co., Tokyo, Japan). The method of color measurement was the so-called Lab system of Hunter, and the color difference, $\Delta \mathrm{E}$, was determined (Japanese Industrial Standards $-\mathrm{Z} 8730$ ).

Values of the Lab system are defined as follows: " $L$ " is the light index; the higher the value, the greater the lightness. "a" and " $b$ " are chromatic indices. A 
plus value of the "a" axis indicates the red color zone and a minus value the green color zone. On the other hand, a plus value of the " $b$ " axis signifies the yellow color zone and a minus value the blue color zone. If coordinates of Lab values are obtained from before-after observations of the specimens in Lab space and are assumed to be $\left(L_{1}, a_{1}, b_{1}\right)$ and $\left(L_{2}, a_{2}, b_{2}\right)$, then differences in these values are $(\Delta \mathrm{L}, \Delta \mathrm{a}, \Delta \mathrm{b})$, and $\Delta \mathrm{E}$ can be calculated from the following expression:

$$
\Delta \mathrm{E}=\sqrt{(\Delta \mathrm{L})^{2}+(\Delta \mathrm{a})^{2}+(\Delta \mathrm{b})^{2}}
$$

\section{Results and Discussion}

\section{I . Glass Ionomer Cement (FIIF)}

The results obtained using specimens of the glass ionomer cement, FIIF, are shown in Figs. 2 and 3. The extent of discoloration ranged from a barely perceptible gray to a very dark gray. The thin disks (Fig. 2), containing $40 \mathrm{ppm}$ of the metal contaminants, showed barely perceptible discoloration after one day (however, in Fig. 2 no differences are discernible).

By both visual and photographic inspection, every thick specimen with added $\mathrm{Pb}, \mathrm{Cu}$ or $\mathrm{Fe}$ up to $40 \mathrm{ppm}$ showed definite discoloration after exposure to the $0.1 \%$ $\mathrm{Na}_{2} \mathrm{~S}$ solution after two days at $55^{\circ} \mathrm{C}$ (Fig. 3). Even the control specimen showed modest, but still significant, discoloration, indicative of the presence of some base metal(s) in this presumably uncontaminated specimen. In the case of exposed specimen $\mathrm{Pb}$ (5)-A, which contained $5 \mathrm{ppm} \mathrm{Pb}$, and the exposed control (Fig. 3), it was difficult to see a significant difference in discoloration, both being light gray. At this level of contamination ( $5 \mathrm{ppm})$, however, the $\mathrm{Cu}$ - and $\mathrm{Fe}$-containing specimens showed increased discoloration compared with the uncontaminated specimens after exposure to $\mathrm{Na}_{2} \mathrm{~S}$. Initial examination of the specimens at regular intervals (e.g. 4h) indicated that a slight change in coloration was gradually occurring in many of the specimens. After one day, the grayish coloration in many of the specimens, though much less pronounced than that observed for the two-day interval, was still clearly evident. However, for the $\mathrm{Cu}$-containing specimens, a less marked change in appearance (dark gray) occurred over this time interval. Without exception, significant discoloration was evident in all the thick contaminated specimens (Fig. 3). The extent of discoloration ranged from light gray to very dark gray. The more modest changes in hue (white to light gray) of the sulfide-exposed, uncontaminated specimens were also significant. Specimens with 0-40 ppm of base metal stored in distilled water at $55^{\circ} \mathrm{C}$ for two days showed no such color changes. The minor variations in the appearance of these control specimens were probably related to the initial color of some of the heavy metal salt solutions and the hydration state of the cement specimen. Specimens of FIIF with added $\mathrm{Cu}$ showed the greatest degree of discoloration even at low metal concentrations. The degree of discoloration of specimens prepared with $\mathrm{Fe}$ and $\mathrm{Pb}$ appeared to be about the same (ranging from light to medium gray). In the case of the Fe-contaminated specimens, the final color may have reflected a mix of the green of ferric sulfide plus the dark gray of ferrous sulfide. For the $\mathrm{Pb}$ - and $\mathrm{Cu}-\mathrm{FIIF}$ specimens, a gradual deepening of the initial light gray color occurred, resulting 
in a relatively dark gray appearance after two days. However, in the case of FIIF specimens with added $\mathrm{Fe}$, a greenish coloration was first noted after about $6 \mathrm{~h}$ of immersion in the $\mathrm{Na}_{2} \mathrm{~S}$ solution. After $24 \mathrm{~h}$ the greenish color gave way to a grayish hue. Presumably the green color was due to the initial formation of ferric sulfide (green), followed by subsequent reduction in the sulfide medium to ferrous sulfide (dark gray). Another reason that may have contributed to the loss of the original green color was the presence of the other metal ions in FIIF which, as they form colored sulfides, may have diluted the green color of ferric sulfide. The state of hydration and/or oxidation state also influenced the observed appearances, as noted by changes which occurred after removal of the specimen from the aqueous environment.

The relatively rapid and marked discoloration occurring in FIIF specimens with added metal contaminants was probably due to the highly hydrophilic and readily permeable nature of glass ionomer cements. With the aid of water molecules, $\mathrm{S}^{2-}$ can diffuse readily into the glass ionomer cement structure and react with available metal ions. A sectioned disk of a thick $(1.5 \mathrm{~mm})$ FIIF specimen containing $40 \mathrm{ppm} \mathrm{Cu}$, after two days at $55^{\circ} \mathrm{C}$ in the $\mathrm{Na}_{2} \mathrm{~S}$ solution, revealed that the discoloration caused by penetration of $\mathrm{S}^{2-}$ occurred throughout the specimen.

\section{Silicophosphate and Silicate Cements-SP-I, SP-II, and S}

The results obtained with the silicophosphate cements, SP-I and SP-II, and the silicate cement, $\mathrm{S}$, are shown in Fig. 4 . As expected, these Pb-containing cements gave specimens which discolored in the presence of $\mathrm{S}^{2-}$.

The specimens submerged in $0.1 \% \mathrm{Na}_{2} \mathrm{~S}$ solution ( $\mathrm{pH} \mathrm{9)}$ at $55^{\circ} \mathrm{C}$ for two days showed discernible discoloration compared to the control specimens (distilled water exposure).

Comparison of the specimens submerged in the $0.1 \% \mathrm{Na}_{2} \mathrm{~S}$ solution revealed that the SP-I (22 ppm Pb) specimens had a light tan hue and the SP-II specimens $(290 \mathrm{ppm} \mathrm{Pb})$ a somewhat darker tan. The extent of discoloration was related to the $\mathrm{Pb}$ content, although this is not evident from the monochrome photographs (Fig. 4). Specimens of $\mathrm{S}(112 \mathrm{ppm} \mathrm{Pb})$ had a pinkish-brown coloration.

The difference in coloration due to lead sulfide formation between the silicophosphate, silicate and the ionomer cements may have been due to the type of $\mathrm{Pb}$ compound(s) present in these materials. The extractability or leachability of $\mathrm{Pb}^{2+}$ as well as the permeability of the materials to $\mathrm{S}^{2-}$ may be a factor in determining the degree and nature of the discoloration phenomenon. It would appear that the leachability of the base metal ion and the permeability of the dental material to $\mathrm{S}^{2-}$ may be of more importance in determining the extent of discoloration than the actual metal content of the restorative. Also, the relative state of hydration and oxidation may affect the overall appearance of these materials.

\section{Composite Materials}

The use of heavy metal contaminants in our study with the commercial composite materals A and I presented some problems in the preliminary screening 
experiments referred to previously. Some of the metal salt solutions (e.g. Table 5, I-d, $0.10 \%, \mathrm{FeCl}_{3}$ in HEMA) with composites I and A caused an immediate color change which persisted in the hardened specimen and made evaluation of further changes in color due to immersion in the $\mathrm{Na}_{2} \mathrm{~S}$ solution difficult to assess. In addition, the $\mathrm{FeCl}_{3}$ solutions severely retarded the curing of I. The hardening of A seemed to be less retarded by the presence of $\mathrm{FeCl}_{3}$. Presumably, there is a color stability problem in the BPO/amine initiator system if significant amounts of $\mathrm{FeCl}_{3}$ are present in the resin. However, some of the preliminary screening results using thin specimens of composites revealed further color changes after exposure to $\mathrm{Na}_{2} \mathrm{~S}$ solution for I contaminated with the following solutions (Table 5 ): $\mathrm{Pb}$ (I-a, I-b), $\mathrm{Cu}$ (I-c, II-c) and Fe (I-f, II-c). The preliminary screening results with A and the $\mathrm{Cu}$ from solution $\mathrm{IIb}$ gave a discernible color change after exposure to the $\mathrm{Na}_{2} \mathrm{~S}$ solution, but the preliminary screening results with the other contaminated specimens of $\mathrm{A}$ were inconclusive.

The preliminary screening results using composite $\mathrm{R}$ indicate that this material has excellent inherent color stability compared with I and A (Table 2). For example, addition of the $\mathrm{FeCl}_{3}$ solution (I-d, I-e, Table 5) to these composites did not discolor the control specimens, and therefore, an evaluation of color changes after exposure to the $\mathrm{Na}_{2} \mathrm{~S}$ solution was possible. In addition, none of the metal-containing contaminant solutions interfered with the hardening reaction as measured by setting times. Also there were no color contributions arising from the initiator system, since $\mathrm{R}$ uses the color-stable hydroperoxide/tertiary aromatic amine. The preliminary screening of $\mathrm{R}$ specimens contaminanted with $\mathrm{Pb}(\mathrm{I}-\mathrm{a}, \mathrm{I}-\mathrm{b})$, $\mathrm{Fe}$ (I-d, I-e), and $\mathrm{Cu}$ (II-b) (Table 5) showed some discoloration on exposure to the $\mathrm{Na}_{2} \mathrm{~S}$ solution.

\section{A. Composite $R$}

Based on the results of preliminary screening, it was decided to perform a quantitative study using $\mathrm{R}$ as the commercial composite. A solution of lead ${ }^{[11]}$ cyclohexanebutyrate (LCB) in BIS-GMA (70\%)/TEGDMA (30\%) (solution II-a) (Table 5), which was colorless, was used as the contaminant solution. The results (Fig. 5) indicated very little, if any, change in coloration over the range $0-40 \mathrm{ppm}$ $\mathrm{Pb}$ after immersion in the $\mathrm{Na}_{2} \mathrm{~S}$ solution at $55^{\circ} \mathrm{C}$ for seven days. After only three days immersion under the same conditions, specimens with higher contents of $\mathrm{Pb}$ (114 and $228 \mathrm{ppm}$ ) showed definite signs of discoloration. Compared to the ionomer cement, composite $\mathrm{R}$ contaminated with $\mathrm{Pb}$ showed far less discoloration. The color stability of the $\mathrm{Pb}$-contaminated composites, in contrast with that of dental cements, was probably the result of the inability of $\mathrm{S}^{2-}$ to diffuse readily into the relatively hydrophobic and less permeable composite specimens.

\section{B. Experimental Hydrophilic Composite-HC}

The results obtained with the experimental hydrophilic composite, HC (Table 2 ), are shown in Fig. 6. After seven days at $55^{\circ} \mathrm{C}$ in the $\mathrm{Na}_{2} \mathrm{~S}$ solution, only the specimen containing $20 \mathrm{ppm} \mathrm{Pb}$ exhibited a positive visual change in color. The $\mathrm{Pb}$-contaminated $\mathrm{Hc}$ composite specimens began showing signs of colorimetric discoloration at a much lower $\mathrm{Pb}$ concentration $(<20 \mathrm{ppm})$ than did composite $\mathrm{R}$ (Fig. 5). As observed with $\mathrm{R}$, the degree of change in hue appeared to be related 
to the concentration of $\mathrm{Pb}$ in the $\mathrm{HC}$ specimens. After exposure to distilled water for seven days at $55^{\circ} \mathrm{C}$, the specimens containing $0-40 \mathrm{ppm} \mathrm{Pb}$ showed only minor color shifts. These results would seem to indicate the easier diffusion of $\mathrm{S}^{2-}$ into the more hydrophilic and relatively more permeable HC specimens. Thus, variations in the hydrophilicity of the matrices of base metal-contaminated esthetic restorations may contribute to the observed differences in discoloration for various dental materials.

\section{Results of Colorimetry}

The results obtained using a dental color analyzer are summarized in Tables 6-10 and Figs. 7-16.

\section{A. Glass Ionomer Cement (FIIF)}

Values of the color shift for thin disks (Fig. 2), containing $40 \mathrm{ppm}$ of the metal contaminants, are shown in Table 6 and Figs. 7,12.

By colorimetric inspection, all of the specimens (except control) showed marked discoloration after exposure to the $0.1 \% \mathrm{Na}_{2} \mathrm{~S}$ solution for one day at $55^{\circ} \mathrm{C}$, those containing $40 \mathrm{ppm} \mathrm{Cu}$ exhibiting an especially marked color shift.

Values of the color shift for regular (thick) specimens (Fig. 3), containing 0-40 ppm of the metal contaminants, are shown in Tables 7-1,-2,-3 and Figs. 8,13-1,-2,-3.

By colorimetric inspection, most of the specimens with $\mathrm{Pb}, \mathrm{Cu}$ or $\mathrm{Fe}$ added up to $40 \mathrm{ppm}$ showed a definite color shift after exposure to the $0.1 \% \mathrm{Na}_{2} \mathrm{~S}$ solution for three days at $55^{\circ} \mathrm{C}$. Again the specimens containing $\mathrm{Cu}$ showed the most significant color shift, and the largest change was observed for $40 \mathrm{ppm} \mathrm{Cu}$. In the case of the specimens preserved in distilled water, some color shift was noted, especially in the "L" index which had large values. This kind of color shift presumably resulted from dehydration of the specimens.

B. Silicophosphate and Silicate Cements-SP-I, SP-II and S

Colorimetric results obtained with silicophosphate cements, SP-I and SP-II, and the silicate cement, $\mathrm{S}$, are shown in Table 8 and Figs. 9,14.

The color differences in the specimens exposed to $0.1 \% \mathrm{Na}_{2} \mathrm{~S}$ solution were compared with those of the specimens exposed to distilled water. The order of decreasing discoloration was as follows: SP-I (22 ppm of $\mathrm{Pb})>\mathrm{S}(112 \mathrm{ppm}$ of $\mathrm{Pb})>$ SP-II $(290 \mathrm{ppm}$ of $\mathrm{Pb}$ ). That is to say, SP-I (which contained the least amount of $\mathrm{Pb}$ ) showed the largest discoloration. The probable cause of this anomalous result was the chemical structure of the $\mathrm{Pb}$ impurity, reducing its leachability from the specimens.

\section{Composite Materials}

1. Composite $R$

Colorimetric results obtained with composite $\mathrm{R}$ (Replica) (Fig. 5) are shown in Table 9 and Figs. 10 and 15. After submersion of the specimens in $0.1 \% \mathrm{Na}_{2} \mathrm{~S}$ for seven days, the values of $\Delta \mathrm{E}$ showed only small differences among those contaminated with $\mathrm{Pb}$ in the range $0-40 \mathrm{ppm}$. These values, however, were still larger than those of the specimens exposed to distilled water.

Specimens with higher contents of $\mathrm{Pb}$ (114 and $228 \mathrm{ppm}$ ) after storage in $0.1 \%$ 
$\mathrm{Na}_{2} \mathrm{~S}$ solution for three days gave $\Delta \mathrm{E}$ values that were significantly larger.

\section{Experimental Hydrophilic Composite-HC}

Values of color shift for hydrophilic composite (Fig. 6) are shown in Table 10 and Figs. 11 and 16.

Values of $\Delta \mathrm{E}$ for the specimens containing between $0-40 \mathrm{ppm} \mathrm{Pb}$ after exposure to $0.1 \% \mathrm{Na}_{2} \mathrm{~S}$ solution were obviously larger than those for similar specimens containing the same amounts of $\mathrm{Pb}$ but exposed to distilled water.

Changes of $\Delta \mathrm{E}$ for the specimens, which were stored in $0.1 \% \mathrm{Na}_{2} \mathrm{~S}$ solution for seven days, were related to the concentration of $\mathrm{Pb}$, the highest concentrations producing the greatest color shift values. The largest color shift was observed in the specimen containing $40 \mathrm{ppm} \mathrm{Pb}$.

\section{General Comments}

Certain esthetic dental restorative materials have been shown to contain modest, but significant amounts of base metals such as $\mathrm{Pb}, \mathrm{Fe}$, and $\mathrm{Cu}$ as contaminants $^{[3,10]}$. The presence of these impurities in a dental cement or composite may eventually diminish the esthetic qualities of these materials through the formation of colored metallic sulfides, as depicted below:

$$
\begin{array}{ll}
\mathrm{M}^{2}+\mathrm{S}^{2-} & \mathrm{MS} \downarrow \\
\mathrm{M}=\mathrm{Pb}, \mathrm{Fe}, \mathrm{Cu} & \text { Colored }
\end{array}
$$

The rate of formation of these sulfides is dependent on several factors:

(1) the type and concentration of the metal contaminant, (2) the extractability of the metal in the form which exists in the hardened dental material, (3) the generation of sulfide ion $\left(\mathrm{S}^{2-}\right)$, hydrogen sulfide $\left(\mathrm{H}_{2} \mathrm{~S}\right)$, etc. in sufficient concentrations in the mouth, and (4) the rate of diffusion of the sulfide chemical species into the hardened dental material. For example, the potential for discoloration due to base metal sulfide formation should be greatest in the case of a permeable, hydrophilic esthetic restoration that contains a high content of leachable base metal (e.g. $\mathrm{Pb}$ ) and is exposed to an oral environment that has some end-products of putrefaction in the form of reactive sulfide moieties.

In a previous study, all specimens of dental cements, but only one of the composites I (Isopast), showed significant discoloration after exposure to an atmosphere of $\mathrm{H}_{2} \mathrm{~S}$ gas at room temperature for up to nine weeks (compared to controls that were exposed only to air) ${ }^{[5]}$. Of all the cements studied, the glass ionomer cements showed the greatest color shifts. The microfilled composite, I (Isopast) which employs a urethane-type dimethacrylate as the principal resin component and has a high organic content, exhibited the greatest color shift of all the composite materials studied ${ }^{[5]}$. The other composite specimens remained virtually unchanged in appearance after exposure to $\mathrm{H}_{2} \mathrm{~S}$. With dental cements, the observed color shifts were ascribed to the presence of certain metal contaminants $(\mathrm{Pb}, \mathrm{Fe}, \mathrm{Cu}$, etc.) which were shown by analysis to be especially prevalent in these materials compared to their occurrence in composite resin materials. For the composite specimens, the occurrence of color shifts is probably influenced more by reactions occurring in the organic matrix (e.g. colored by-products resulting from 
the tertiary aromatic amine/benzoyl peroxide oxidation-reduction initiation reaction) than from the presence of base metal contaminants. The severe discoloration observed in the case of composite I (Isopast) also may originate from colorgenerating reactions involving $\mathrm{H}_{2} \mathrm{~S}$ and certain sites, perhaps the urethane groups, present in the organic phase of this material. An alternate explanation may involve the ease of formation of colored sulfides from trace amounts of base metals (e.g. residual tin catalysts, such as stannous octoate, used in the preparation of the urethane resin) which are available for reaction with $\mathrm{H}_{2} \mathrm{~S}$ or $\mathrm{S}^{2-}$ because of the relatively more hydrophilic and permeable nature of this microfilled composite compared to the other commercial composites that have higher filler contents.

In the present study, an aqueous solution of $0.1 \%(\mathrm{w} / \mathrm{v})$ sodium sulfide $\left(\mathrm{Na}_{2} \mathrm{~S}\right)$, adjusted to $\mathrm{pH} 9$, was used instead of $\mathrm{H}_{2} \mathrm{~S}$ gas ${ }^{[5]}$ as the medium for exposing a number of hardened dental materials to a sulfide environment. Generally speaking, the discoloration of specimens prepared from the same dental materials was greater after exposure to $\mathrm{H}_{2} \mathrm{~S}$ gas at room temperature than after immersion in the $\mathrm{Na}_{2} \mathrm{~S}$ solution at $37^{\circ} \mathrm{C}$ or even at $55^{\circ} \mathrm{C}$. Exposure to the $\mathrm{Na}_{2} \mathrm{~S}$ solution at $55^{\circ} \mathrm{C}$ was designed as an accelerated test procedure.

\section{Conclusions}

An aqueous solution of $0.1 \% \mathrm{Na}_{2} \mathrm{~S}(\mathrm{pH}=9)$ is an effective medium for inducing discoloration in esthetic dental restorative materials containing base metal contaminants. The results obtained with this solution are similar to those obtained previously using $\mathrm{H}_{2} \mathrm{~S}$ gas ${ }^{[5]}$.

Glass ionomer cements exhibit greater discoloration due to base metal contaminants than do composite resin materials containing equivalent amounts of the same metals.

The extent of discoloration is dependent on (a) the nature of the metal contaminant, its concentration, and leachability and (b) the hydrophilicity and permeability to $\mathrm{S}^{2-}$ (or other sulfide-generating chemical species) of the hardened dental material.

\section{Acknowledgement}

Grateful appreciation is expressed to Dr. Alan D. Wilson, of the Laboratory of the Government Chemists (Cornwall House, Stamford Street, London SEI, England), for the silicophosphate and silicate samples and their analyses.

\section{References}

[1] Dental Metallurgy: an advertising brochure published by the Keller Medicine Co., Fort Wayne, Indiana, 1985

[2] Souder, W.: Standards for dental materials, JADA, 22: 1873-1978, 1935

[3] Paffenbarger, G. C., Schoonover, I. C. and Souder, W.: Dental silicate cements: Physical and chemical properties and a specification, $J A D A, 25,32-37,1938$

[4] BS 3365 Specification Dental Silicate Cement and Dental Silico-phosphate Cement Part 1: 1980. Dental Cement (handmixed) Part 2:1971. Dental Silico-phosphate cements Part 3: 1981. BS 3364: Specification for Dental Zinc Phosphate Cement: 1980. BS 6039 Specification for Dental Glass Ionomer Cements: 1981. 
[5] Sugawara, A.: Effects of hydrogen sulfide gas on discoloration of esthetic restorative materials, J. J. Dent. Mater., 2, 381-400, 1983

[6] Mithio, Ando: A study of discoloration of dental silver amalgam, J. DAM, 11, 1-14, 1970

[7] Chen, T. M. and Brauer, G. M.: Application of silane coupling agent to inorganic components of composites, J. Dent. Res., 60 (Special Issue), 369, 1981.

[8] Chen, T. M. and Brauer, G. M.: Solvent effects on bonding silane to silica surfaces, J. Dent. Res., 61, 1439-1443, 1982

[9] Antonucci, J. M., Grams, C. L. and Termini, D. J.: New initiator systems for dental resins based on ascorbic acid, J. Dent. Res., 58, 1887-1899, 1971

[10] Sugawara, A. and Ohashi, M: A study for discoloration of esthetic restorative materials with reference to the relationship between the discoloration and the elements, J. J. Dent. Mater., 3, 562-573, 1984 
Table 1 Monomers and Accelerators Used in Preparing Heavy Metal Solutions and an Experimental Hydrophilic Composite

\begin{tabular}{|c|c|c|}
\hline Name & Acroynm & Source \\
\hline $\begin{array}{l}2,2,- \text { BIS [p-(y-methacryloxy- } \\
\beta \text {-hydroxypropoxy) phenyl] propane }\end{array}$ & $\overline{\mathrm{BIS}-\mathrm{GMA}}$ & $\begin{array}{l}\text { Freeman Chemical Co. } \\
\text { Milwaukee, WI }\end{array}$ \\
\hline Triethylene glycol dimethacrylate & TEDGMA & $\begin{array}{l}\text { Esschem Co. } \\
\text { Essington, PA }\end{array}$ \\
\hline 2-Hydroxyethyl methacrylate & HEMA & $\begin{array}{l}\text { Esschem Co. } \\
\text { Essington, PA }\end{array}$ \\
\hline Ascorbic acid & AA & $\begin{array}{l}\text { Hoffmann-LaRoche Inc. } \\
\text { Nutley, NJ }\end{array}$ \\
\hline Ascorbyl palmitate & AP & $\begin{array}{l}\text { Hoffmann-LaRoche Inc. } \\
\text { Nutley, NJ }\end{array}$ \\
\hline
\end{tabular}

Table 2 Dental Materials Tested

$\frac{\text { A: Commercial } \frac{\text { Type of Material }}{\text { Materials (Batch No.) }}}{\text { Adaptic (2754) }}$

Isopast (00228)

Replica (0041)

Fuji Ionomer-

Type 11F (291101)

Silicophosphate cement-I

(containing $22 \mathrm{ppm} \mathrm{Pb}$ )

Silicophosphate cement-II

(containing $290 \mathrm{ppm} \mathrm{Pb}$ and $3 \mathrm{ppm}$ total

As $(0.5 \mathrm{ppm}$ water-soluble As)

Silicate cement

(containing $112 \mathrm{ppm} \mathrm{Kb}$ )

\section{B: Experimental Material}

Hydrophilic composite

Powder-Silanized Glass Filler*

Liquid-BIS-GMA 74.4 (wt \%)

HEMA 24.8 ( wt \%)

Accelerators-AA, 0.4 (wt \%)

AP, 0.4 (wt \%)

Code $\quad$ Source

A Johnson \& Johnson

Dental Products Division

East Windsor, NJ

I Vivadent

Buffalo, NY

R Hoyt Laboratories

Norwood, MA

F11F G-C International

Tokyo, Japan 174

SP-I

SP-II Samples and analyses furnished by Alan Wilson, Laboratory of the Government Chemist, London SEl 9NO,

United Kingdom

S

HC National Institute of Standards and Technology, Gaithersburg, MD

* Corning glass 7724,325 mesh was silanized with $0.5 \%$ by weight 3 -methacryoxypropyltrimethoxysilane ${ }^{[7,8]}$ and then coated with $1 \%$ by weight benzoyl peroxide (BP). 
Table 3 Heavy Metal Compounds Used as Contaminants

\begin{tabular}{|c|c|}
\hline Salt (code) & Source \\
\hline \multicolumn{2}{|l|}{$\mathrm{Pb}$} \\
\hline $\begin{array}{c}\text { Lead cyclohexanebutyrate } \\
\text { (LCB) }\end{array}$ & $\begin{array}{l}\text { Eastman Kodak Co. } \\
\text { Rochester, NY }\end{array}$ \\
\hline $\begin{array}{l}\text { Lead nitrate } \\
\qquad(\mathrm{LN})\end{array}$ & $\begin{array}{l}\text { J.T. Baker Chemical Co. } \\
\text { Phillipsburg, NY }\end{array}$ \\
\hline $\begin{array}{l}\text { Lead acetate } \\
\text { (LA) }\end{array}$ & $\begin{array}{l}\text { Fisher Scientific Co. } \\
\text { Fairlawn, NY }\end{array}$ \\
\hline \multicolumn{2}{|l|}{$\mathrm{Cu}$} \\
\hline $\begin{array}{c}\text { Copper(II) benzoylacetonate } \\
\text { (CBA) }\end{array}$ & $\begin{array}{l}\text { Eastman Kodak Co. } \\
\text { Rochester NY }\end{array}$ \\
\hline $\begin{array}{r}\text { Cupric acetate } \\
\text { (CA) }\end{array}$ & $\begin{array}{l}\text { Fisher Scientific Co. } \\
\text { Fairlawn, NY }\end{array}$ \\
\hline \multicolumn{2}{|l|}{$\mathrm{Fe}$} \\
\hline $\begin{array}{r}\text { Ferric chloride } \\
\left(\mathrm{F}_{3} \mathrm{C}\right)\end{array}$ & $\begin{array}{l}\text { Allied Chemical } \\
\text { Morristown, NJ }\end{array}$ \\
\hline $\begin{array}{l}\text { Ferrous chloride } \\
\qquad\left(\mathrm{F}_{2} \mathrm{C}\right)\end{array}$ & $\begin{array}{l}\text { Fisher Scientific Co. } \\
\text { Fairlawn, NJ }\end{array}$ \\
\hline $\begin{array}{r}\text { Ferric oxalate } \\
\text { (FO) }\end{array}$ & $\begin{array}{l}\text { Alfa Products } \\
\text { Danvers, MA }\end{array}$ \\
\hline $\begin{array}{l}\text { Ferric benzoylacetonate } \\
\text { (FBA) }\end{array}$ & $\begin{array}{l}\text { Eastman Kodak Co. } \\
\text { Rochester, NY }\end{array}$ \\
\hline
\end{tabular}

Table 4 Solutions* of Heavy Metal Salts Used for Contamination of Glass Ionomer Cement (F11F)

\begin{tabular}{|c|c|c|}
\hline $\begin{array}{l}\text { Code for } \\
\text { etal Solution }\end{array}$ & $\begin{array}{c}\text { Metal } \\
\text { Salt }\end{array}$ & (wt \%) \\
\hline A & LCB & $(0.15)$ \\
\hline B & $\mathrm{LN}$ & $(0.30)$ \\
\hline $\mathrm{C}$ & LA & $(0.30)$ \\
\hline $\mathrm{D}$ & CBA & $(0.15)$ \\
\hline $\mathrm{E}$ & $\mathrm{CA}$ & $(0.15)$ \\
\hline $\mathrm{F}$ & FO & $(0.30)$ \\
\hline
\end{tabular}

* Solvent for metal salt solutions consisted of a mixture of $95 \%$ by weight F11F liquid (Table 2) and $5 \%$ by weight distilled water. 
Table 5 Solutions of Metal Salts Used for Contamination of Composite Specimens

\begin{tabular}{|c|c|c|c|c|c|}
\hline $\begin{array}{c}\text { Code for } \\
\text { Metal Solution }\end{array}$ & $\begin{array}{c}\text { Metal } \\
\text { Salt }\end{array}$ & (wt \%) & Solvent & (wt \%) & $\begin{array}{c}\text { Composites Used } \\
\text { with Solution }\end{array}$ \\
\hline $\mathrm{I}-\mathrm{a}$ & LCB & $(0.30)$ & HEMA & (100) & R, A. I \\
\hline $\mathrm{b}$ & LCB & $(0.10)$ & HEMA & (100) & $\mathrm{R}, \mathrm{A}, \mathrm{I}$ \\
\hline c & $\mathrm{CA}$ & $(0.05)$ & HEMA & $(100)$ & $\mathrm{R}, \mathrm{A}, \mathrm{I}$ \\
\hline $\mathrm{d}$ & $\mathrm{F}_{3} \mathrm{C}$ & $(1.00)$ & HEMA & $(100)$ & $\mathrm{R}, \mathrm{A}, \mathrm{I}$ \\
\hline $\mathrm{e}$ & $\mathrm{F}_{3} \mathrm{C}$ & $(0.10)$ & HEMA & (100) & $\mathrm{R}, \mathrm{A}, \mathrm{I}$ \\
\hline f & $\mathrm{F}_{2} \mathrm{C}$ & $(0.10)$ & HEMA & $(100)$ & $\mathrm{R}, \mathrm{A}, \mathrm{I}$ \\
\hline II $-\mathrm{a}$ & LCB & $(0.30)$ & $\begin{array}{c}\text { BIS-GMA } \\
+\end{array}$ & (70) & $\mathrm{R}, \mathrm{A}, \mathrm{I}$ \\
\hline $\mathrm{b}$ & $\mathrm{CBA}$ & $(0.15)$ & TEGDMA & (30) & $\mathrm{R}, \mathrm{A}, \mathrm{I}$ \\
\hline c & FBA & $(0.04)$ & & & $\mathrm{R}, \mathrm{A}, \mathrm{I}$ \\
\hline III & LCB & $(0.25)$ & $\begin{array}{c}\text { BIS-GMA } \\
+ \\
\text { HEMA }\end{array}$ & $\begin{array}{l}(75) \\
(25)\end{array}$ & $\mathrm{HC}$ \\
\hline
\end{tabular}

Table 6 Results of Discoloration (Fuji Ionomer Type II F-Thin Disks)

\begin{tabular}{|c|c|c|c|c|c|c|c|c|c|}
\hline \multirow{2}{*}{ Specimen } & \multirow{2}{*}{ Time } & \multicolumn{3}{|c|}{ Distilled Water $-55^{\circ} \mathrm{C}$} & \multirow{2}{*}{$\Delta \mathrm{E}$} & \multicolumn{3}{|c|}{$0.1 \% \mathrm{Na}_{2} \mathrm{~S}(\mathrm{pH} 9)-55^{\circ} \mathrm{C}$} & \multirow{2}{*}{$\Delta \mathrm{E}$} \\
\hline & & $\mathrm{L}$ & $\mathrm{a}$ & $\mathrm{b}$ & & $\mathrm{L}$ & $\mathrm{a}$ & b & \\
\hline \multirow{4}{*}{ Control } & $0 \mathrm{~d}$ & 60.3 & -0.6 & -15.6 & \multirow{4}{*}{4.8} & 62.4 & -1.0 & -16.7 & \multirow{4}{*}{5.0} \\
\hline & S.D. & 1.06 & 0.40 & 0.40 & & 0.21 & 0.21 & 0.42 & \\
\hline & $1 \mathrm{~d}$ & 55.7 & -0.1 & -14.3 & & 57.6 & 0.0 & -15.8 & \\
\hline & S.D. & 0.36 & 0.32 & 0.21 & & 0.30 & 0.25 & 0.23 & \\
\hline \multirow{4}{*}{$\mathrm{Pb}-\mathrm{A}$} & $0 \mathrm{~d}$ & 63.3 & -1.2 & -15.3 & \multirow{4}{*}{3.5} & 61.6 & -0.6 & -16.3 & \multirow{4}{*}{18.7} \\
\hline & S.D. & 0.61 & 0.17 & 0.21 & & 0.35 & 0.14 & 0.42 & \\
\hline & $1 \mathrm{~d}$ & 60.2 & -0.6 & -16.8 & & 43.3 & 0.1 & -12.7 & \\
\hline & S.D. & 0.31 & 0.06 & 0.17 & & 0.91 & 0.29 & 0.38 & \\
\hline \multirow{4}{*}{$\mathrm{Cu}-\mathrm{D}$} & $0 \mathrm{~d}$ & 58.9 & -1.6 & -16.8 & \multirow{4}{*}{4.7} & 58.3 & -2.2 & -17.6 & \multirow{4}{*}{53.9} \\
\hline & S.D. & 0.29 & 0.15 & 0.10 & & 0.70 & 0.10 & 0.21 & \\
\hline & $1 \mathrm{~d}$ & 54.6 & -0.7 & -18.5 & & 7.6 & 3.6 & -0.3 & \\
\hline & S.D. & 0.47 & 0.06 & 0.25 & & 0.70 & 0.26 & 0.00 & \\
\hline \multirow{4}{*}{$\mathrm{Cu}-\mathrm{E}$} & $0 \mathrm{~d}$ & 58.5 & -3.2 & -16.4 & \multirow{4}{*}{4.4} & 60.4 & -3.2 & -16.4 & \multirow{4}{*}{59.6} \\
\hline & S.D. & 0.17 & 0.06 & 0.23 & & 0.45 & 0.20 & 0.26 & \\
\hline & $1 \mathrm{~d}$ & 62.8 & -3.8 & -17.4 & & 3.2 & 2.3 & -0.5 & \\
\hline & S.D. & 0.61 & 0.12 & 0.47 & & 0.36 & 0.00 & 0.06 & \\
\hline \multirow{4}{*}{$\mathrm{Fe}-\mathrm{F}$} & $0 \mathrm{~d}$ & 61.5 & -1.3 & -15.9 & \multirow{4}{*}{5.8} & 58.5 & -0.7 & -17.0 & \multirow{4}{*}{22.2} \\
\hline & S.D. & 0.61 & 0.15 & 0.21 & & 0.60 & 0.21 & 0.25 & \\
\hline & $1 \mathrm{~d}$ & 67.3 & -1.7 & -15.7 & & 38.4 & -0.2 & -7.5 & \\
\hline & S.D. & 0.47 & 0.15 & 0.15 & & 1.72 & 0.23 & 0.26 & \\
\hline
\end{tabular}


Table 7-1 Results of Discoloration (Fuji Ionomer Type IIF-Thick Disks)

\begin{tabular}{|c|c|c|c|c|c|c|c|c|c|}
\hline \multirow{2}{*}{ Specimen } & \multirow{2}{*}{ Time } & \multicolumn{3}{|c|}{ Distilled Water $-55^{\circ} \mathrm{C}$} & \multirow{2}{*}{$\Delta \mathrm{E}$} & \multicolumn{3}{|c|}{$0.1 \% \mathrm{Na}_{2} \mathrm{~S}(\mathrm{pH} 9)-55^{\circ} \mathrm{C}$} & \multirow{2}{*}{$\Delta \mathrm{E}$} \\
\hline & & $\mathrm{L}$ & $\mathrm{a}$ & $\mathrm{b}$ & & $\mathrm{L}$ & $\mathrm{a}$ & $\mathrm{b}$ & \\
\hline \multirow{4}{*}{ Control } & $0 \mathrm{~d}$ & 54.7 & 0.6 & -17.8 & \multirow{4}{*}{11.1} & 54.4 & 0.3 & -17.9 & \multirow{4}{*}{4.1} \\
\hline & S.D. & 0.06 & 0.21 & 0.20 & & 0.32 & 0.06 & 0.20 & \\
\hline & $3 \mathrm{~d}$ & 65.7 & -0.3 & -18.4 & & 57.9 & 0.3 & -15.7 & \\
\hline & S.D. & 0.31 & 0.15 & 0.23 & & 0.10 & 0.15 & 0.12 & \\
\hline \multirow{4}{*}{$\mathrm{Pb}(5)-\mathrm{A}$} & $0 \mathrm{~d}$ & 64.8 & -1.4 & -17.4 & \multirow{4}{*}{1.3} & 63.0 & 0.9 & -17.9 & \multirow{4}{*}{8.0} \\
\hline & S.D. & 0.30 & 0.36 & 0.21 & & 0.25 & 0.15 & 0.00 & \\
\hline & $3 \mathrm{~d}$ & 64.9 & -0.5 & -18.4 & & 55.6 & 0.0 & -14.9 & \\
\hline & S.D. & 0.52 & 0.10 & 0.21 & & 0.58 & 0.00 & 0.26 & \\
\hline \multirow{4}{*}{$\mathrm{Pb}(10)-\mathrm{A}$} & $0 \mathrm{~d}$ & 55.2 & 0.5 & -17.8 & \multirow{4}{*}{11.2} & 55.9 & 0.2 & -17.3 & \multirow{4}{*}{2.2} \\
\hline & S.D. & 0.12 & 0.15 & 0.25 & & 0.12 & 0.21 & 0.26 & \\
\hline & $3 \mathrm{~d}$ & 66.3 & -0.8 & -18.4 & & 54.9 & 0.0 & -15.3 & \\
\hline & S.D. & 0.21 & 0.17 & 0.21 & & 0.10 & 0.12 & 0.15 & \\
\hline \multirow{4}{*}{$\mathrm{Pb}(20)-\mathrm{A}$} & $0 \mathrm{~d}$ & 54.3 & 0.4 & -17.5 & \multirow{4}{*}{10.6} & 53.9 & 0.4 & -17.7 & \multirow{4}{*}{4.1} \\
\hline & S.D. & 0.00 & 0.15 & 0.17 & & 0.42 & 0.12 & 0.26 & \\
\hline & $3 \mathrm{~d}$ & 64.8 & -0.7 & -18.8 & & 50.2 & 0.7 & -15.9 & \\
\hline & S.D. & 0.21 & 0.15 & 0.15 & & 0.30 & 0.10 & 1.79 & \\
\hline \multirow{4}{*}{$\mathrm{Pb}(40)-\mathrm{A}$} & $0 \mathrm{~d}$ & 64.8 & -0.6 & -18.4 & \multirow{4}{*}{2.9} & 54.9 & 1.1 & -18.1 & \multirow{4}{*}{7.0} \\
\hline & S.D. & 0.23 & 0.06 & 0.25 & & 0.06 & 0.10 & 0.06 & \\
\hline & $3 d$ & 67.7 & -0.6 & -18.7 & & 49.6 & 0.0 & -13.7 & \\
\hline & S.D. & 0.64 & 0.23 & 0.44 & & 0.44 & 0.35 & 0.20 & \\
\hline \multirow{4}{*}{$\mathrm{Pb}(40)-\mathrm{B}$} & $0 \mathrm{~d}$ & 53.1 & 1.2 & -17.6 & \multirow{4}{*}{13.0} & 53.6 & 0.6 & -17.8 & \multirow{4}{*}{14.0} \\
\hline & S.D. & 0.35 & 0.20 & 0.15 & & 0.21 & 0.31 & 0.23 & \\
\hline & $3 \mathrm{~d}$ & 65.9 & -0.5 & -18.7 & & 40.4 & 1.9 & -13.4 & \\
\hline & S.D. & 0.20 & 0.00 & 0.10 & & 0.06 & 0.10 & 0.17 & \\
\hline \multirow{4}{*}{$\mathrm{Pb}(40)-\mathrm{C}$} & $0 \mathrm{~d}$ & 53.6 & 0.7 & -17.3 & \multirow{4}{*}{11.6} & 53.4 & 0.9 & -17.6 & \multirow{4}{*}{15.4} \\
\hline & S.D. & 0.10 & 0.09 & 0.06 & & 0.12 & 0.21 & 0.10 & \\
\hline & $3 d$ & 65.2 & 0.5 & -18.1 & & 38.1 & 2.1 & -13.5 & \\
\hline & S.D. & 0.15 & 0.31 & 0.06 & & 0.21 & 0.15 & 0.15 & \\
\hline
\end{tabular}


Table 7-2 Results of Discoloration (Fuji Ionomer Type IIF-Thick Disks)

\begin{tabular}{|c|c|c|c|c|c|c|c|c|c|}
\hline \multirow{2}{*}{ Specimen } & \multirow{2}{*}{ Time } & \multicolumn{3}{|c|}{ Distilled Water $-55^{\circ} \mathrm{C}$} & \multirow{2}{*}{$\Delta \mathrm{E}$} & \multicolumn{3}{|c|}{$0.1 \% \mathrm{Na}_{2} \mathrm{~S}(\mathrm{pH} 9)-55^{\circ} \mathrm{C}$} & \multirow{2}{*}{$\Delta \mathrm{E}$} \\
\hline & & $\mathrm{L}$ & $\mathrm{a}$ & $\mathrm{b}$ & & $\mathrm{L}$ & $\mathrm{a}$ & b & \\
\hline \multirow{4}{*}{$\mathrm{Cu}(5)-\mathrm{D}$} & $0 \mathrm{~d}$ & 54.8 & 0.2 & -17.4 & \multirow{4}{*}{9.8} & 54.4 & 0.7 & -17.2 & \multirow{4}{*}{5.7} \\
\hline & S.D. & 0.23 & 0.23 & 0.12 & & 0.17 & 0.06 & 0.15 & \\
\hline & $3 \mathrm{~d}$ & 64.5 & -0.8 & -18.3 & & 50.9 & -0.5 & -12.8 & \\
\hline & S.D. & 0.35 & 0.06 & 0.21 & & 0.15 & 0.31 & 0.17 & \\
\hline \multirow{4}{*}{$\mathrm{Cu}(10)-\mathrm{D}$} & $0 \mathrm{~d}$ & 54.4 & -0.3 & -17.7 & \multirow{4}{*}{10.3} & 54.9 & -0.2 & -18.1 & \multirow{4}{*}{25.2} \\
\hline & S.D. & 0.23 & 0.20 & 0.06 & & 0.06 & 0.23 & 0.15 & \\
\hline & $3 \mathrm{~d}$ & 64.6 & -1.4 & -18.3 & & 32.1 & 3.2 & -7.9 & \\
\hline & S.D. & 0.15 & 0.21 & 0.15 & & 0.61 & 0.35 & 0.25 & \\
\hline \multirow{4}{*}{$\mathrm{Cu}(20)-\mathrm{D}$} & $0 \mathrm{~d}$ & 54.0 & -0.7 & -17.3 & \multirow{4}{*}{11.1} & 53.0 & -0.6 & -17.3 & \multirow{4}{*}{36.9} \\
\hline & S.D. & 0.06 & 0.06 & 0.21 & & 0.06 & 0.06 & 0.35 & \\
\hline & $3 \mathrm{~d}$ & 65.0 & -1.8 & -18.3 & & 18.8 & 4.0 & -4.1 & \\
\hline & S.D. & 0.17 & 0.06 & 0.15 & & 0.32 & 0.12 & 0.12 & \\
\hline \multirow{4}{*}{$\mathrm{Cu}(40)-\mathrm{D}$} & $0 \mathrm{~d}$ & 52.4 & -1.4 & -17.2 & \multirow{4}{*}{11.7} & 52.9 & -1.5 & -17.6 & \multirow{4}{*}{49.8} \\
\hline & S.D. & 0.12 & 0.30 & 0.15 & & 0.12 & 0.10 & 0.17 & \\
\hline & $3 \mathrm{~d}$ & 64.0 & -2.8 & -18.4 & & 6.5 & 4.0 & -0.3 & \\
\hline & S.D. & 0.31 & 0.23 & 0.40 & & 0.15 & 0.26 & 0.25 & \\
\hline \multirow{4}{*}{$\mathrm{Cu}(5)-\mathrm{E}$} & 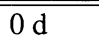 & 55.9 & 0.0 & -18.0 & \multirow{4}{*}{10.5} & 54.4 & 0.1 & -17.7 & \multirow{4}{*}{14.6} \\
\hline & S.D. & 0.15 & 0.10 & 0.23 & & 0.17 & 0.20 & 0.17 & \\
\hline & $3 \mathrm{~d}$ & 66.2 & 1.3 & -19.0 & & 41.4 & 1.4 & -11.2 & \\
\hline & S.D. & 0.15 & 0.42 & 0.15 & & 0.35 & 0.15 & 0.06 & \\
\hline \multirow{4}{*}{$\mathrm{Cu}(10)-\mathrm{E}$} & $0 \mathrm{~d}$ & 54.8 & 0.0 & -17.6 & \multirow{4}{*}{10.3} & 56.2 & 0.3 & -17.7 & \multirow{4}{*}{23.0} \\
\hline & S.D. & 0.21 & 0.12 & 0.21 & & 0.20 & 0.12 & 0.10 & \\
\hline & $3 \mathrm{~d}$ & 65.0 & 0.6 & -18.6 & & 35.4 & 2.4 & -8.1 & \\
\hline & S.D. & 0.58 & 0.35 & 0.32 & & 0.23 & 0.21 & 0.12 & \\
\hline \multirow{4}{*}{$\mathrm{Cu}(20)-\mathrm{E}$} & $0 \mathrm{~d}$ & 53.9 & -0.6 & -17.3 & \multirow{4}{*}{12.4} & 54.7 & -0.7 & -17.2 & \multirow{4}{*}{29.2} \\
\hline & S.D. & 0.21 & 0.17 & 0.12 & & 0.12 & 0.06 & 0.1 & \\
\hline & $3 d$ & 66.2 & -2.2 & -18.1 & & 28.1 & 3.3 & -5.9 & \\
\hline & S.D. & 0.20 & 0.10 & 0.12 & & 0.45 & 0.10 & 0.21 & \\
\hline & $0 \mathrm{~d}$ & 54.2 & -1.3 & -17.3 & & 54.7 & -1.4 & -17.2 & \\
\hline C (40)-E & S.D. & 0.21 & 0.21 & 0.10 & 105 & 0.12 & 0.12 & 0.12 & 138 \\
\hline $\mathrm{Cu}(40)-\mathrm{E}$ & $3 \mathrm{~d}$ & 64.6 & -2.8 & -18.1 & 10.5 & 13.6 & 5.4 & -3.8 & 43.0 \\
\hline & S.D. & 0.21 & 0.30 & 0.25 & & 0.23 & 0.10 & 0.21 & \\
\hline
\end{tabular}


Table 7-3 Results of Discoloration (Fuji Ionomer Type IIF-Thick Disks)

\begin{tabular}{|c|c|c|c|c|c|c|c|c|c|}
\hline \multirow{2}{*}{ Specimen } & \multirow{2}{*}{ Time } & \multicolumn{3}{|c|}{ Distilled Water $-55^{\circ} \mathrm{C}$} & \multirow{2}{*}{$\Delta \mathrm{E}$} & \multicolumn{3}{|c|}{$0.1 \% \mathrm{Na}_{2} \mathrm{~S}(\mathrm{pH} 9)-55^{\circ} \mathrm{C}$} & \multirow{2}{*}{$\Delta \mathrm{E}$} \\
\hline & & $\mathrm{L}$ & $\mathrm{a}$ & $\mathrm{b}$ & & $\mathrm{L}$ & $\mathrm{a}$ & $\mathrm{b}$ & \\
\hline \multirow{4}{*}{$\mathrm{Fe}(5)-\mathrm{F}$} & $0 \mathrm{~d}$ & 54.8 & 0.6 & -18.0 & \multirow{4}{*}{13.1} & 53.1 & 0.9 & -17.8 & \multirow{4}{*}{11.7} \\
\hline & S.D. & 0.29 & 0.12 & 0.30 & & 0.20 & 0.36 & 0.10 & \\
\hline & $3 \mathrm{~d}$ & 67.8 & 1.0 & -19.2 & & 43.5 & 0.3 & -11.2 & \\
\hline & S.D. & 0.38 & 0.06 & 0.10 & & 0.44 & 0.15 & 0.17 & \\
\hline \multirow{4}{*}{$\mathrm{Fe}(10)-\mathrm{F}$} & $0 \mathrm{~d}$ & 54.5 & 0.4 & -17.8 & \multirow{4}{*}{11.9} & 55.2 & 0.3 & -17.7 & \multirow{4}{*}{17.0} \\
\hline & S.D. & 0.12 & 0.21 & 0.21 & & 0.06 & 0.21 & 0.30 & \\
\hline & $3 \mathrm{~d}$ & 66.4 & 0.6 & -18.8 & & 39.8 & 0.7 & -10.5 & \\
\hline & S.D. & 0.31 & 0.15 & 0.15 & & 0.55 & 0.25 & 0.17 & \\
\hline \multirow{4}{*}{$\mathrm{Fe}(20)-\mathrm{F}$} & $0 \mathrm{~d}$ & 56.1 & 0.8 & -18.7 & \multirow{4}{*}{8.1} & 55.6 & 0.8 & -18.6 & \multirow{4}{*}{14.6} \\
\hline & S.D. & 0.20 & 0.12 & 0.21 & & 0.15 & 0.30 & 0.10 & \\
\hline & $3 d$ & 64.0 & 0.4 & -20.2 & & 42.8 & 0.1 & -11.7 & \\
\hline & S.D. & 0.40 & 0.32 & 0.29 & & 0.31 & 0.21 & 0.10 & \\
\hline \multirow{4}{*}{$\mathrm{Fe}(40)-\mathrm{F}$} & $0 \mathrm{~d}$ & 54.3 & 0.8 & -19.3 & \multirow{4}{*}{11.9} & 55.3 & 1.0 & -18.6 & \multirow{4}{*}{20.4} \\
\hline & S.D. & 0.15 & 0.15 & 0.15 & & 0.12 & 0.20 & 0.06 & \\
\hline & $3 \mathrm{~d}$ & 66.1 & -0.5 & -20.3 & & 36.7 & 0.5 & -10.3 & \\
\hline & S.D. & 0.06 & 0.21 & 0.00 & & 0.36 & 0.06 & 0.12 & \\
\hline
\end{tabular}

Table 8 Results of Discoloration (Silicophosphate and Silice Cements Having Known Amount of $\mathrm{Pb}$ )

\begin{tabular}{|c|c|c|c|c|c|c|c|c|c|}
\hline \multirow{2}{*}{ Specimen } & \multirow{2}{*}{ Time } & \multicolumn{3}{|c|}{ Distilled Water $-55^{\circ} \mathrm{C}$} & \multirow{2}{*}{$\Delta \mathrm{E}$} & \multicolumn{3}{|c|}{$0.1 \% \mathrm{Na}_{2} \mathrm{~S}(\mathrm{pH} 9)-55^{\circ} \mathrm{C}$} & \multirow{2}{*}{$\Delta \mathrm{E}$} \\
\hline & & $\mathrm{L}$ & a & b & & $\mathrm{L}$ & a & $\mathrm{b}$ & \\
\hline \multirow{4}{*}{$\begin{array}{c}\text { SP-I } \\
(22 \mathrm{ppm})\end{array}$} & $0 \mathrm{~d}$ & 34.8 & 6.1 & -32.1 & \multirow{4}{*}{8.1} & 38.3 & 6.5 & -31.7 & \multirow{4}{*}{24.7} \\
\hline & S.D. & 0.06 & 0.10 & 0.15 & & 0.46 & 0.12 & 0.35 & \\
\hline & & 35.6 & 6.7 & -24.5 & & 19.7 & 14.8 & -17.8 & \\
\hline & S.D. & 0.32 & 0.12 & 0.26 & & 0.21 & 0.10 & 0.35 & \\
\hline \multirow{4}{*}{$\begin{array}{c}\mathrm{S} \\
(112 \mathrm{ppm})\end{array}$} & $0 \mathrm{~d}$ & 34.6 & 6.0 & -25.3 & \multirow{4}{*}{1.5} & 34.1 & 6.3 & -25.4 & \multirow{4}{*}{17.2} \\
\hline & S.D. & 0.78 & 0.35 & 0.68 & & 0.49 & 0.15 & 0.40 & \\
\hline & $2 d$ & 36.0 & 6.2 & -24.9 & & 20.2 & 13.3 & -18.1 & \\
\hline & S.D. & 0.20 & 0.15 & 0.00 & & 0.00 & 0.17 & 0.35 & \\
\hline \multirow{4}{*}{$\begin{array}{c}\text { SP- II } \\
(290 \mathrm{ppm})\end{array}$} & $0 \mathrm{~d}$ & 58.3 & 0.3 & -32.7 & \multirow{4}{*}{8.7} & 58.9 & 0.6 & -32.6 & \multirow{4}{*}{13.8} \\
\hline & S.D. & 0.49 & 0.42 & 0.53 & & 0.25 & 0.51 & 0.25 & \\
\hline & $2 d$ & 50.9 & 1.9 & -28.4 & & 47.0 & 5.2 & -27.3 & \\
\hline & S.D. & 0.12 & 0.10 & 0.29 & & 0.40 & 0.20 & 0.42 & \\
\hline
\end{tabular}


Table 9 Results of Discoloration (Replica)

\begin{tabular}{|c|c|c|c|c|c|c|c|c|c|}
\hline \multirow{2}{*}{ Specimen } & \multirow{2}{*}{ Time } & \multicolumn{3}{|c|}{ Distilled Water $-55^{\circ} \mathrm{C}$} & \multirow{2}{*}{$\Delta \mathrm{E}$} & \multicolumn{3}{|c|}{$0.1 \% \mathrm{Na}_{2} \mathrm{~S}(\mathrm{pH} 9)-55^{\circ} \mathrm{C}$} & \multirow{2}{*}{$\Delta \mathrm{E}$} \\
\hline & & $\mathrm{L}$ & $\mathrm{a}$ & $\mathrm{b}$ & & $\mathrm{L}$ & $\mathrm{a}$ & $\mathrm{b}$ & \\
\hline \multirow{4}{*}{$\mathrm{R}-0$} & $0 \mathrm{~d}$ & 70.1 & -1.5 & -22.9 & \multirow{4}{*}{9.6} & 70.3 & -1.4 & -22.9 & \multirow{4}{*}{26.8} \\
\hline & S.D. & 0.36 & 0.10 & 0.40 & & 0.62 & 0.06 & 0.90 & \\
\hline & $7 \mathrm{~d}$ & 60.7 & 0.4 & -23.1 & & 44.5 & 2.3 & -16.7 & \\
\hline & S.D. & 0.06 & 0.06 & 0.21 & & 0.38 & 0.15 & 0.56 & \\
\hline \multirow{4}{*}{$\mathrm{R}-5$} & $0 \mathrm{~d}$ & 70.7 & -1.5 & -22.8 & \multirow{4}{*}{9.2} & 70.6 & -1.6 & -22.9 & \multirow{4}{*}{24.9} \\
\hline & S.D. & 0.32 & 0.06 & 0.46 & & 0.61 & 0.15 & 0.61 & \\
\hline & $7 \mathrm{~d}$ & 61.6 & -0.1 & -23.3 & & 46.3 & 2.1 & -18.8 & \\
\hline & S.D. & 0.23 & 0.44 & 0.64 & & 0.81 & 0.10 & 0.55 & \\
\hline \multirow{4}{*}{$\mathrm{R}-10$} & $0 \mathrm{~d}$ & 69.9 & -1.6 & -22.6 & \multirow{4}{*}{11.8} & 71.1 & -1.8 & -22.6 & \multirow{4}{*}{28.1} \\
\hline & S.D. & 0.51 & 0.23 & 0.70 & & 0.40 & 0.31 & 0.40 & \\
\hline & $7 \mathrm{~d}$ & 58.4 & 0.6 & -21.4 & & 43.9 & 2.3 & -17.1 & \\
\hline & S.D. & 0.72 & 0.12 & 0.49 & & 0.64 & 0.10 & 0.26 & \\
\hline \multirow{4}{*}{$\mathrm{R}-20$} & $0 \mathrm{~d}$ & 71.5 & -2.0 & -22.7 & \multirow{4}{*}{11.1} & 70.4 & -1.8 & -22.7 & \multirow{4}{*}{26.7} \\
\hline & S.D. & 0.35 & 0.35 & 0.35 & & 0.21 & 0.25 & 0.23 & \\
\hline & $7 \mathrm{~d}$ & 60.6 & 0.2 & -22.7 & & 44.4 & 2.6 & -18.3 & \\
\hline & S.D. & 0.30 & 0.06 & 0.40 & & 0.78 & 0.35 & 0.70 & \\
\hline \multirow{4}{*}{$\mathrm{R}-40$} & $0 \mathrm{~d}$ & 71.5 & -2.0 & -22.1 & \multirow{4}{*}{14.0} & 71.2 & -2.0 & -21.7 & \multirow{4}{*}{26.2} \\
\hline & S.D. & 0.35 & 0.25 & 0.36 & & 0.20 & 0.21 & 0.38 & \\
\hline & $7 d$ & 58.7 & 2.0 & -26.1 & & 45.4 & 1.9 & -19.0 & \\
\hline & S.D. & 0.40 & 0.10 & 0.35 & & 0.93 & 0.20 & 0.67 & \\
\hline \multirow{4}{*}{ R-114 } & & 73.9 & -3.1 & -19.9 & \multirow{4}{*}{7.0} & 75.1 & -2.7 & -19.8 & \multirow{4}{*}{38.7} \\
\hline & S.D. & 0.35 & 0.17 & 0.35 & & 0.45 & 0.32 & 0.47 & \\
\hline & $3 \mathrm{~d}$ & 67.0 & -1.8 & -20.1 & & 37.4 & 5.2 & -16.4 & \\
\hline & S.D. & 0.17 & 0.38 & 0.26 & & 1.05 & 0.12 & 0.61 & \\
\hline \multirow{4}{*}{$\mathrm{R}-228$} & & 76.2 & -3.3 & -16.4 & \multirow{4}{*}{1.9} & 76.8 & -3.3 & -16.7 & \multirow{4}{*}{53.1} \\
\hline & S.D. & 0.31 & 0.68 & 0.25 & & 0.62 & 0.40 & 0.38 & \\
\hline & $3 \mathrm{~d}$ & 76.3 & -2.7 & -18.2 & & 25.2 & 8.6 & -12.7 & \\
\hline & S.D. & 0.49 & 0.47 & 0.36 & & 0.31 & 0.20 & 0.46 & \\
\hline
\end{tabular}

Table 10 Results of Discoloration (Experimental Hydrophilic Composite Resin)

\begin{tabular}{|c|c|c|c|c|c|c|c|c|c|}
\hline \multirow{2}{*}{ Specimen } & \multirow{2}{*}{ Time } & \multicolumn{3}{|c|}{ Distilled Water $-55^{\circ} \mathrm{C}$} & \multirow{2}{*}{$\Delta \mathrm{E}$} & \multicolumn{3}{|c|}{$0.1 \% \mathrm{Na}_{2} \mathrm{~S}(\mathrm{pH} 9)-55^{\circ} \mathrm{C}$} & \multirow{2}{*}{$\Delta \mathrm{E}$} \\
\hline & & $\mathrm{L}$ & $\mathrm{a}$ & $\mathrm{b}$ & & $\mathrm{L}$ & $\mathrm{a}$ & $\mathrm{b}$ & \\
\hline \multirow{4}{*}{$\mathrm{HC}-0$} & $0 \mathrm{~d}$ & 80.8 & -3.4 & -14.3 & \multirow{4}{*}{6.8} & 81.0 & -3.8 & -14.4 & \multirow{4}{*}{13.8} \\
\hline & S.D. & 0.53 & 0.15 & 0.31 & & 0.47 & 0.15 & 0.30 & \\
\hline & $7 \mathrm{~d}$ & 77.4 & -3.1 & -20.2 & & 69.0 & -3.7 & -21.2 & \\
\hline & S.D. & 0.67 & 0.32 & 0.52 & & 0.53 & 0.23 & 0.26 & \\
\hline \multirow{4}{*}{$\mathrm{HC}-5$} & $0 \mathrm{~d}$ & 80.9 & -4.4 & -15.7 & \multirow{4}{*}{8.3} & 81.5 & -4.2 & -15.3 & \multirow{4}{*}{14.9} \\
\hline & S.D. & 0.45 & 0.45 & 0.59 & & 0.51 & 0.00 & 0.32 & \\
\hline & $7 \mathrm{~d}$ & 74.8 & -3.2 & -21.2 & & 68.4 & -1.3 & -21.7 & \\
\hline & S.D. & 0.30 & 0.70 & 0.42 & & 1.01 & 0.31 & 0.44 & \\
\hline \multirow{4}{*}{$\mathrm{HC}-10$} & $0 \mathrm{~d}$ & 81.1 & -4.3 & -14.8 & \multirow{4}{*}{9.1} & 81.0 & -4.4 & -16.2 & \multirow{4}{*}{17.9} \\
\hline & S.D. & 0.75 & 0.45 & 1.59 & & 0.46 & 0.21 & 0.38 & \\
\hline & $7 \mathrm{~d}$ & 79.5 & -2.4 & -21.5 & & 64.8 & -0.3 & -22.7 & \\
\hline & S.D. & 0.53 & 0.42 & 0.70 & & 0.40 & 0.15 & 0.26 & \\
\hline \multirow{4}{*}{$\mathrm{HC}-20$} & $0 \mathrm{~d}$ & 81.5 & -4.7 & -16.4 & \multirow{4}{*}{11.0} & 81.7 & -4.5 & -16.3 & \multirow{4}{*}{20.9} \\
\hline & S.D. & 0.46 & 0.21 & 0.35 & & 0.26 & 0.20 & 0.29 & \\
\hline & $7 \mathrm{~d}$ & 73.7 & -2.3 & -23.8 & & 63.1 & 1.3 & -24.0 & \\
\hline & S.D. & 0.46 & 0.21 & 0.10 & & 0.31 & 0.47 & 0.35 & \\
\hline \multirow{4}{*}{$\mathrm{HC}-40$} & $0 \mathrm{~d}$ & 80.4 & -4.6 & -17.0 & \multirow{4}{*}{6.7} & 80.8 & -5.0 & -17.7 & \multirow{4}{*}{29.0} \\
\hline & S.D. & 0.32 & 0.35 & 0.06 & & 0.30 & 0.23 & 0.25 & \\
\hline & $7 \mathrm{~d}$ & 79.8 & -3.8 & -23.6 & & 53.7 & 3.9 & -23.1 & \\
\hline & S.D. & 0.52 & 0.53 & 0.17 & & 0.32 & 0.31 & 0.20 & \\
\hline
\end{tabular}




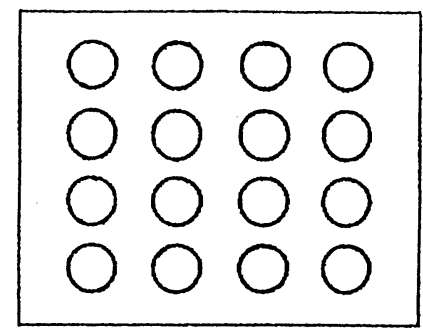

Top View

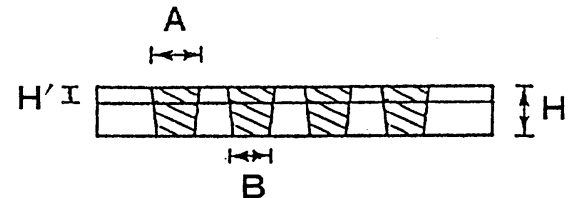

Side View

The top diameter, $A$, of each tapered, cylindrical mold is $7.5 \mathrm{~mm}$ while the bottom diameter, $B$, is $7.0 \mathrm{~mm}$. The height, $\mathrm{H}$, of the molds for thick specimens is $1.5 \mathrm{~mm}$; for thin specimens, the height, $\mathrm{H}^{\prime}$, of the slightly tapered mold is $0.35 \mathrm{~mm}$.

Fig. 1 Schematic Representation of Polytetrafluoroethylene Mold Used in Specimen Preparation

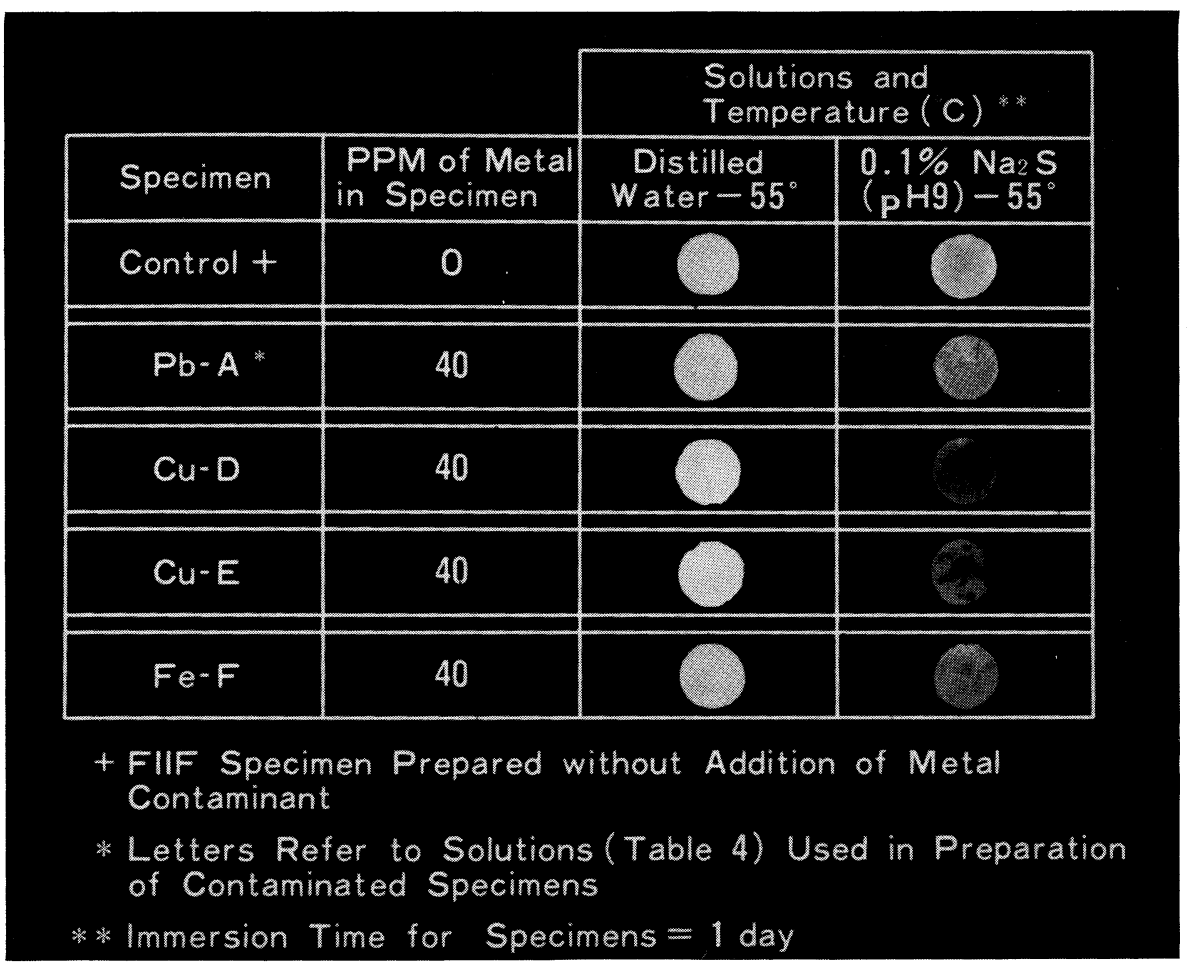

Fig. 2 Discoloration of FIIF Thin (0.35 mm) Disks Containing $40 \mathrm{ppm}$ of Lead, Copper or Iron 


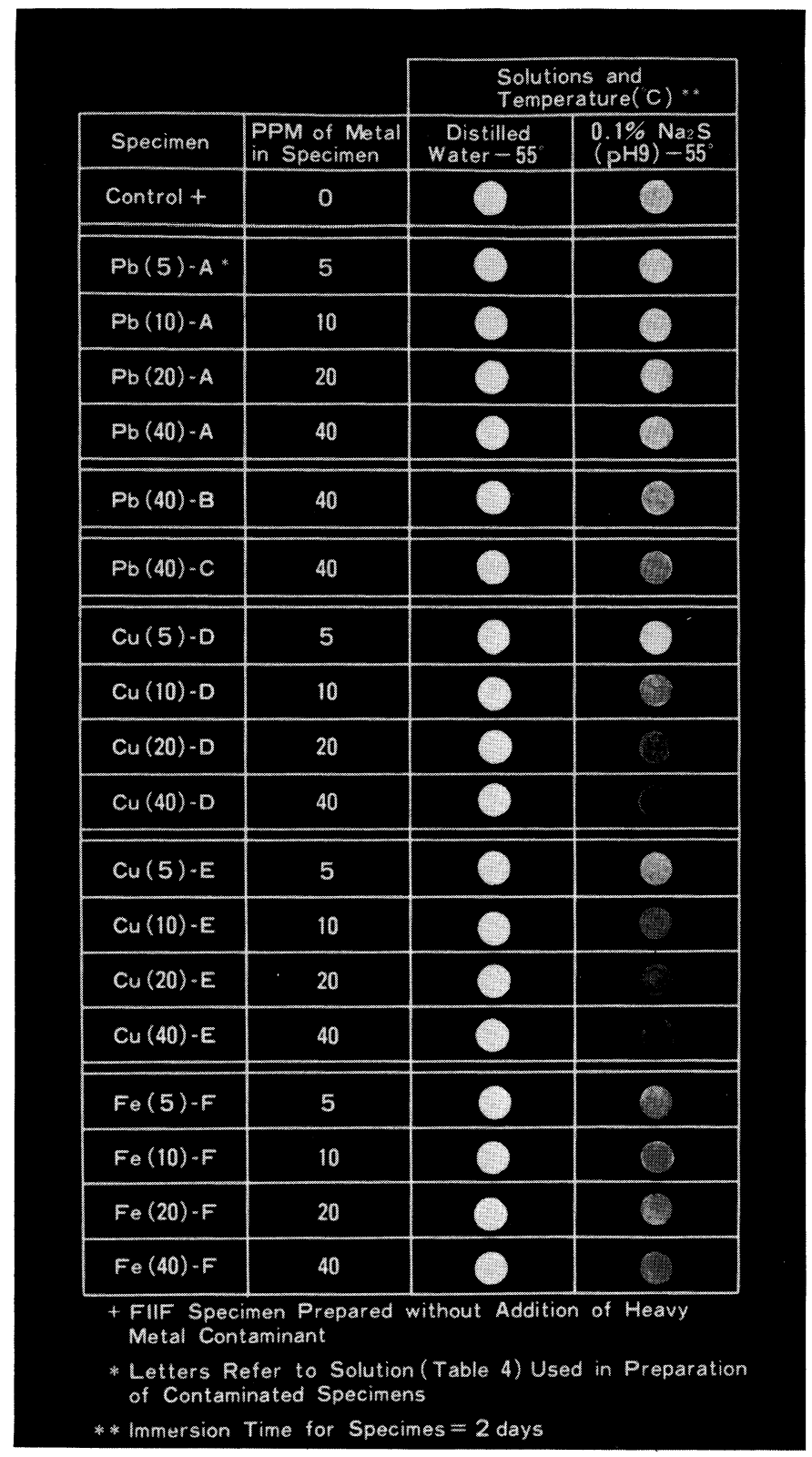

Fig. 3 Discoloration of FIIF Thick $(1.5 \mathrm{~mm})$ Specimens Contaminated with Varying Amounts of Base Metals 


\begin{tabular}{|c|c|c|c|}
\cline { 3 - 4 } \multicolumn{2}{c|}{} & \multicolumn{2}{c|}{$\begin{array}{c}\text { Solutions and } \\
\text { Temperature ( }) *\end{array}$} \\
\hline Specimen * & $\begin{array}{c}\text { PPM of Pb } \\
\text { in Specimen * }\end{array}$ & $\begin{array}{c}\text { Distilled } \\
\text { Water }-55^{\circ}\end{array}$ & $\begin{array}{c}0.1 \% \text { Na2 S } \\
(\mathrm{pH})-55^{\circ}\end{array}$ \\
\hline SP-1 & 22 & & \\
\hline S & 112 & & \\
\hline SP-II & 290 & & \\
\hline
\end{tabular}

* Immersion Time for Specimens $=2$ days.

* Samples and Lead Determinations were Obtained from Alan Wilson. Laboratory of the Government Chemist London. U.K.

Fig. 4 Discoloration of Silicophosphate and Silicate Cements Having Known Amounts of $\mathrm{Pb}$ in Specimens

\begin{tabular}{|c|c|c|c|}
\hline \multirow[b]{2}{*}{ Specimen } & \multirow[b]{2}{*}{$\begin{array}{l}\mathrm{PPM} \text { of } \mathrm{Pb}^{*} \\
\text { in Specimen }\end{array}$} & \multicolumn{2}{|c|}{$\begin{array}{l}\text { Solutions and } \\
\text { Temperature }(\mathrm{C})^{* *}\end{array}$} \\
\hline & & $\begin{array}{r}\text { Distilled } \\
\text { Water }-55^{\circ}\end{array}$ & $\begin{array}{l}0.1 \% \mathrm{Na}_{2} \mathrm{~S} \\
(\mathrm{pH})-55^{\circ}\end{array}$ \\
\hline$R-0$ & 0 & & \\
\hline$R-5$ & 5 & & \\
\hline$R-10$ & 10 & & \\
\hline$R-20$ & 20 & & \\
\hline$R-40$ & 40 & & \\
\hline$R-114$ & 114 & & O \\
\hline$R-228$ & 228 & 0 & (6) \\
\hline
\end{tabular}

* Source of $\mathrm{Pb}$ is Solution lla (Table 5 )

** Immersion Time for Specimens R-0 to R-40=7 days

Immersion Time for Specimens R-114 and R-228 $=3$ days

Fig. 5 Discoloration of Composite R Specimens Contaminated with Increasing Amounts of $\mathrm{Pb}$ 


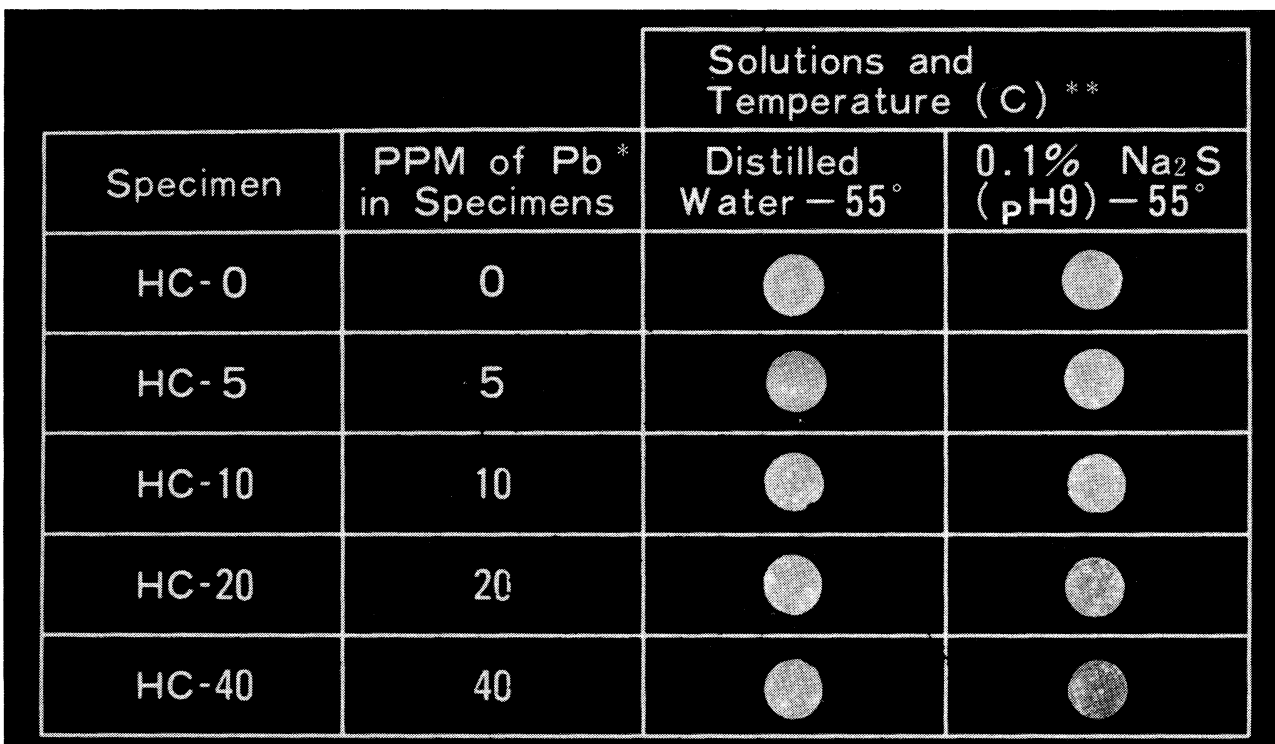

* Source of $\mathrm{Pb}$ is Solution III (Table 5)

$* *$ Immersion time for Specimens $=7$ days

Fig. 6 Discoloration of Experimental Hydrophilic Composite Specimens (HC) Contaminated with Increasing Amounts of $\mathrm{Pb}$

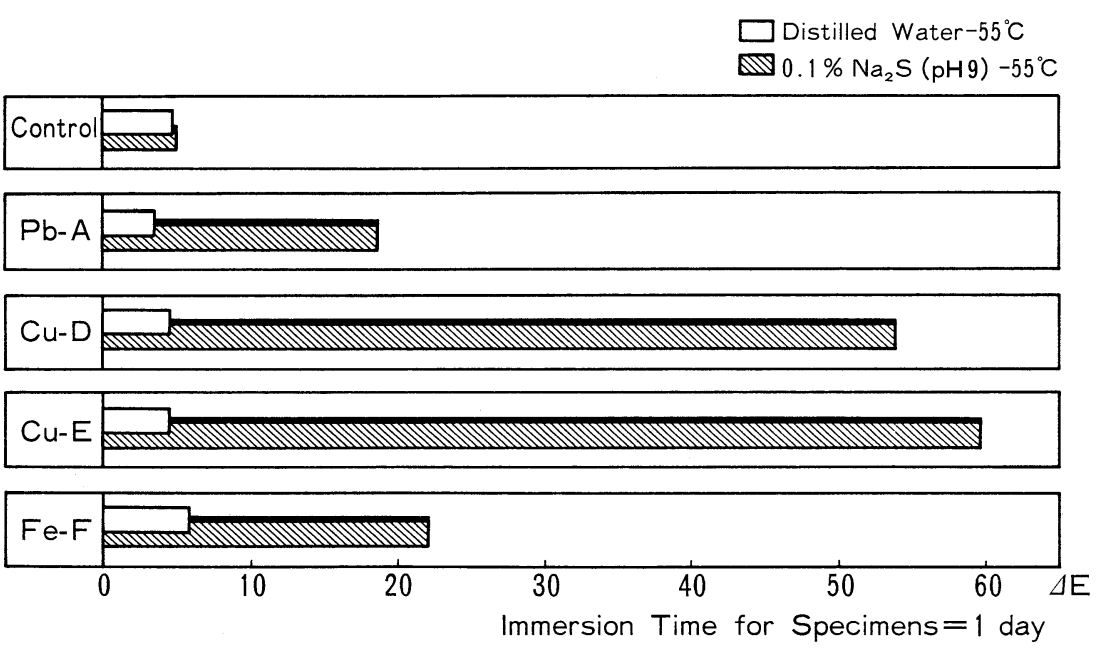

Fig. 7 Discoloration of FIIF Thin $(0.35 \mathrm{~mm})$ Disks Containing $40 \mathrm{ppm}$ of Lead, Copper or Iron 

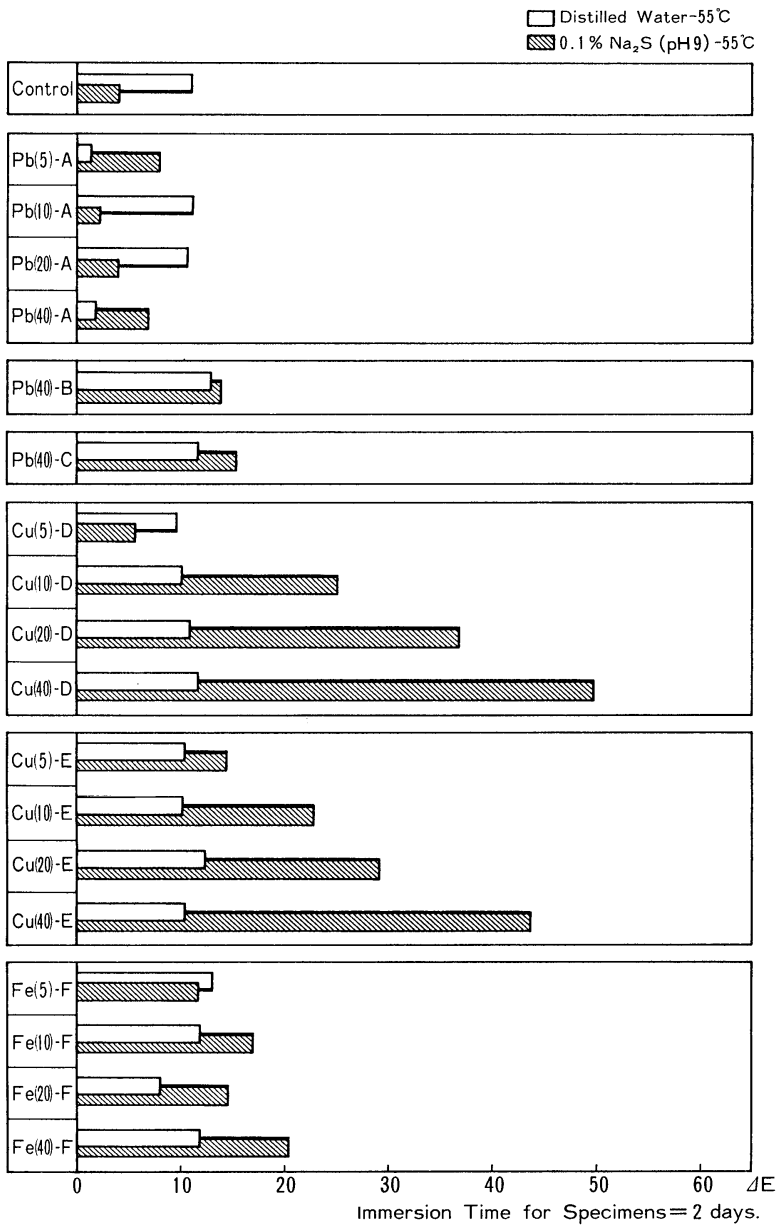

Fig. 8 Discoloration of FIIF Thick $(1.5 \mathrm{~mm})$ Specimens Contaminated with Varying Amounts of Base Metals

$\square$ Distilled Water $-55^{\circ} \mathrm{C}$

$0.1 \% \mathrm{Na}_{2} \mathrm{~S}(\mathrm{pH} 9)-55^{\circ} \mathrm{C}$
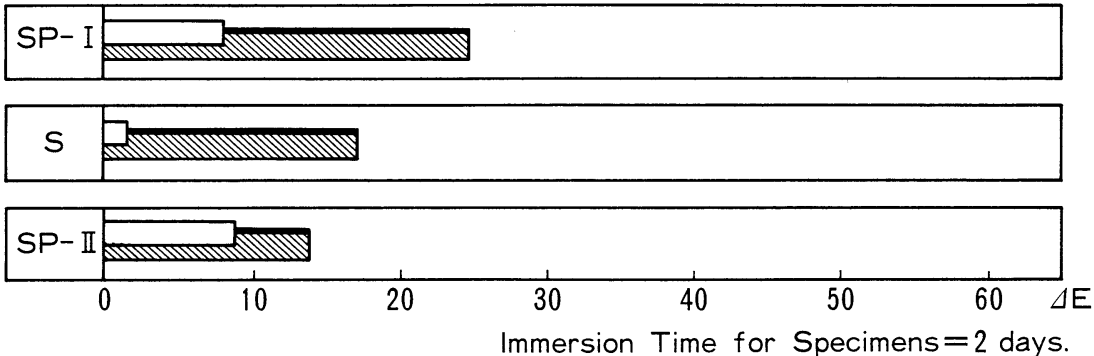

Fig. 9 Discoloration of Silicophosphate and Silicate Cements Having Known Amounts of $\mathrm{Pb}$ in Specimens 

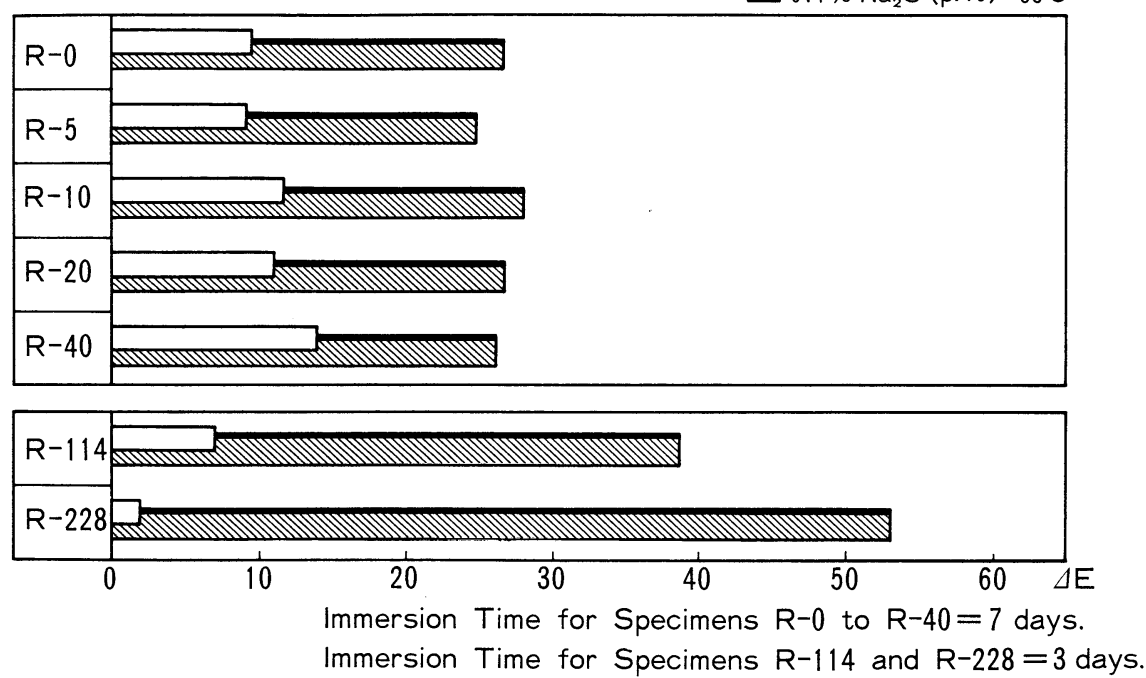

Fig. 10 Discoloration of Composite R Specimens Contaminated with Increasing Amounts of $\mathrm{Pb}$

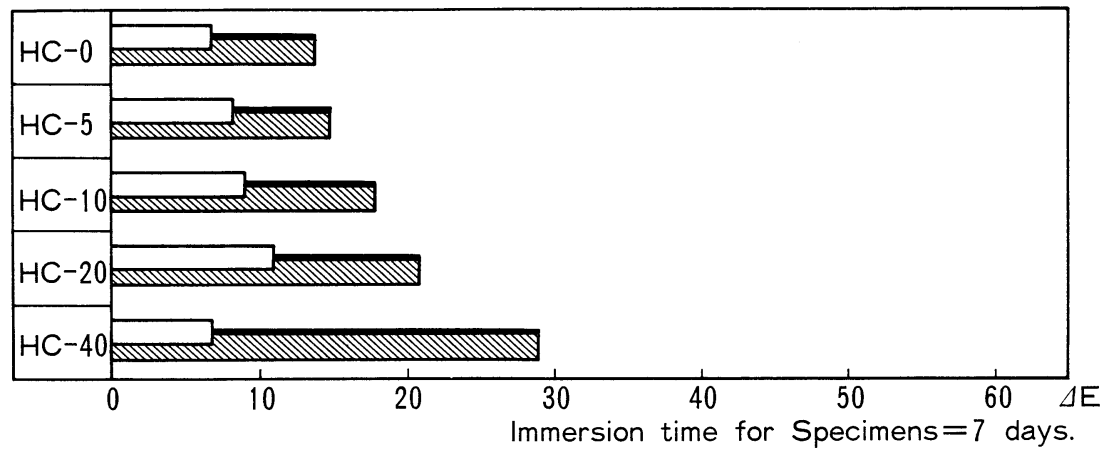

Fig. 11 Discoloration of Experimental Hydrophilic Composite Specimens (HC) Contaminated with Increasing Amounts of $\mathrm{Pb}$ 


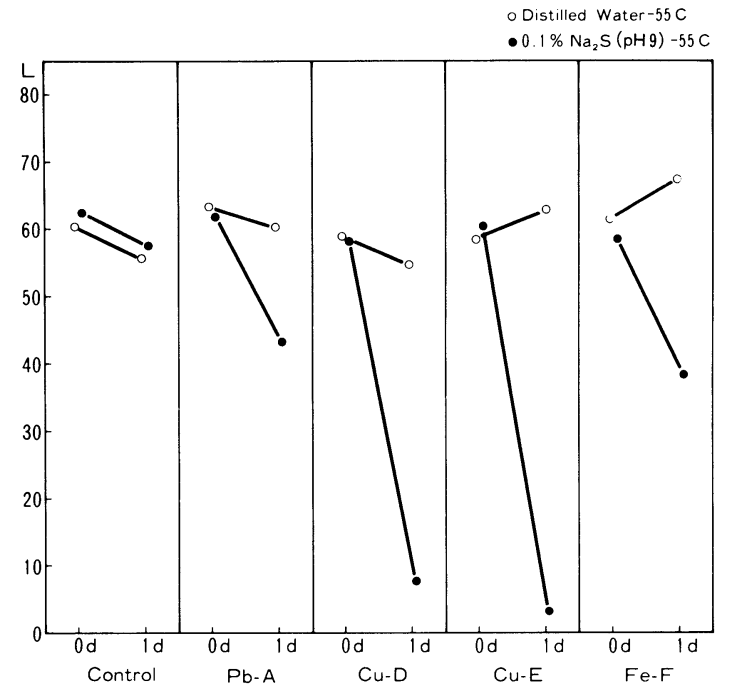

Fig. 12 Discoloration of FIIF Thin $(0.35 \mathrm{~mm})$ Disks Containing $40 \mathrm{ppm}$ of Lead, Copper or Iron

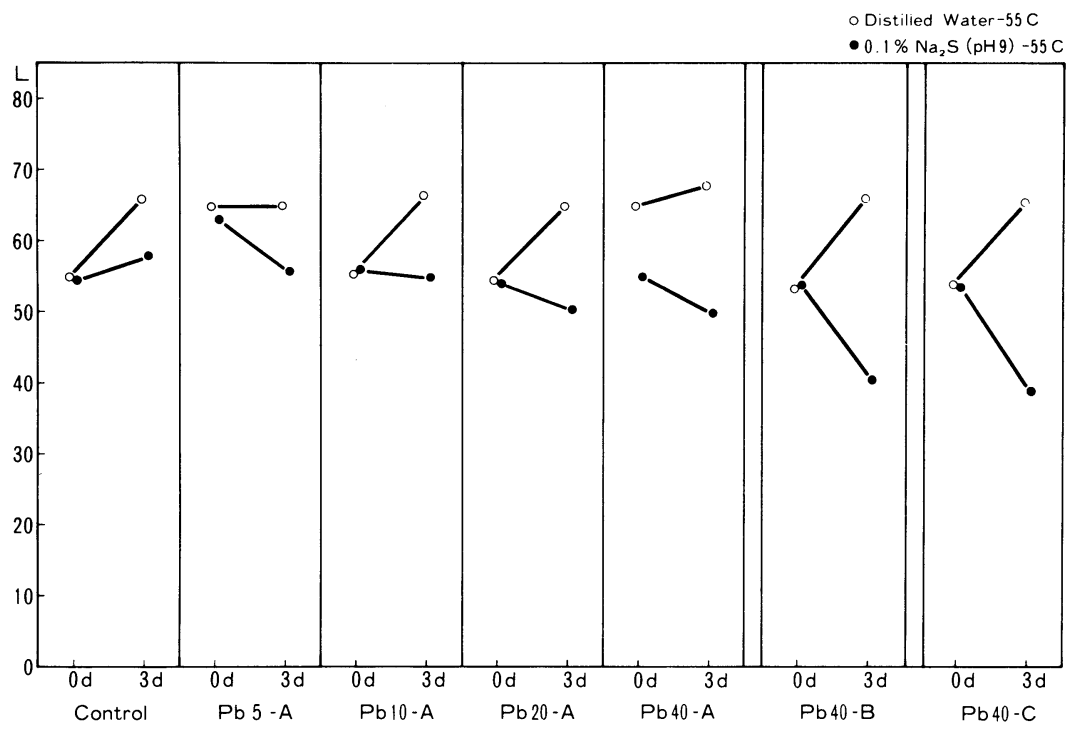

Fig. 13-1 Discoloration of FIIF Thick $(1.5 \mathrm{~mm})$ Specimens Contaminated with Varying Amounts of Base Metals 


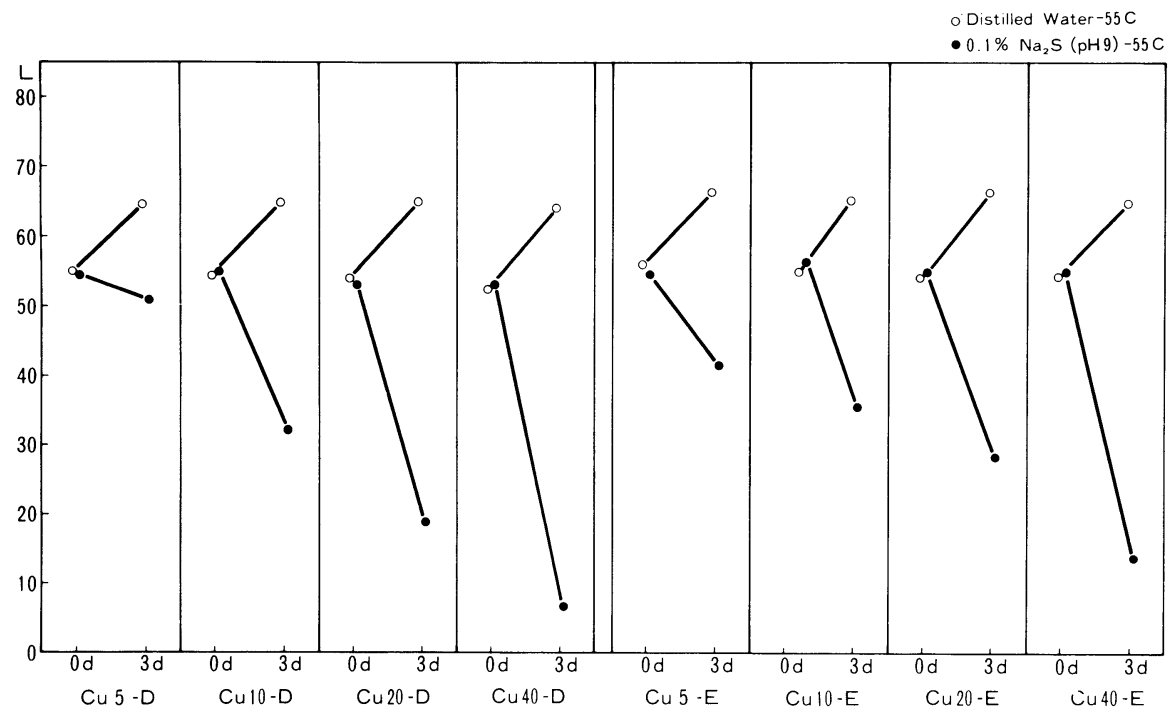

Fig. 13-2 Discoloration of FIIF Thick $(1.5 \mathrm{~mm})$ Specimens Contaminated with Varying Amounts of Base Metals

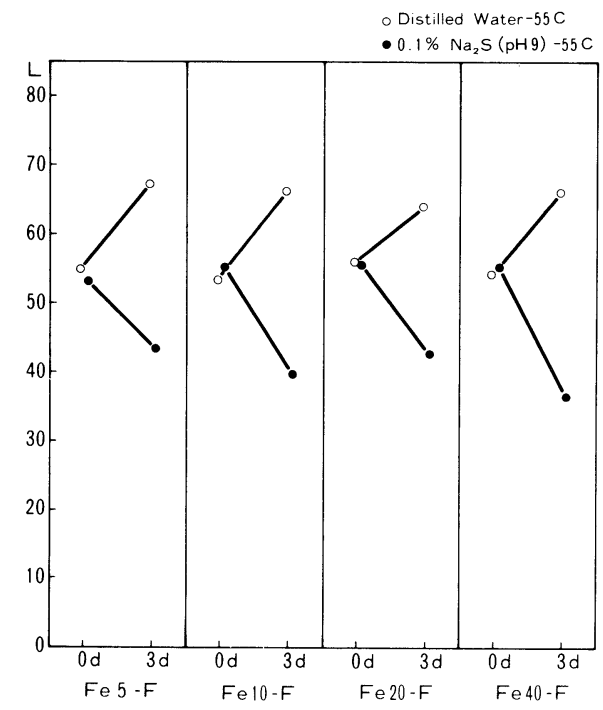

Fig. 13-3 Discoloration of F IIF Thick (1.5 mm) Specimens Contaminated with Varying Amounts of Base Metals 


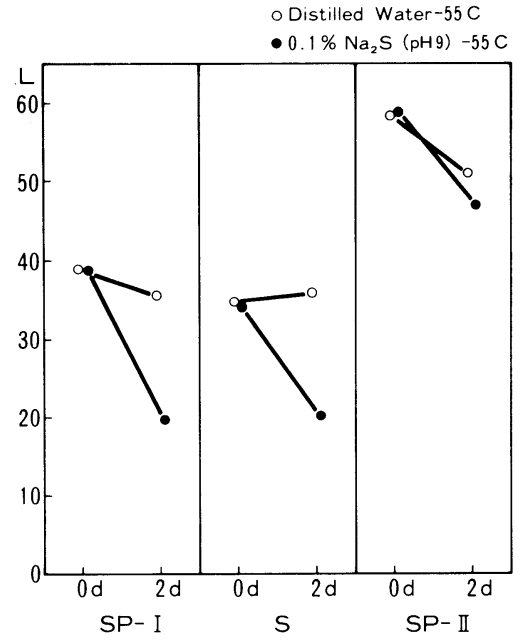

Fig. 14 Discoloration of Silicophosphate and Silicate Cements Having Known Amounts of $\mathrm{Pb}$ in Specimens

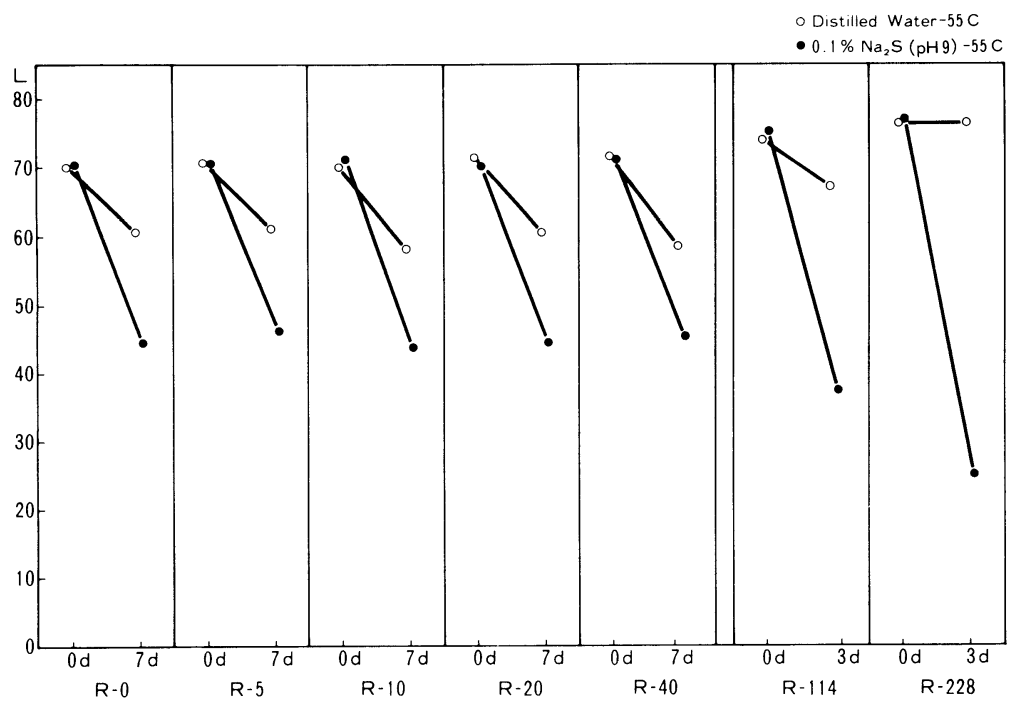

Fig. 15 Discoloration of Composite R Specimens Contaminated with Increasing Amounts of $\mathrm{Pb}$ 


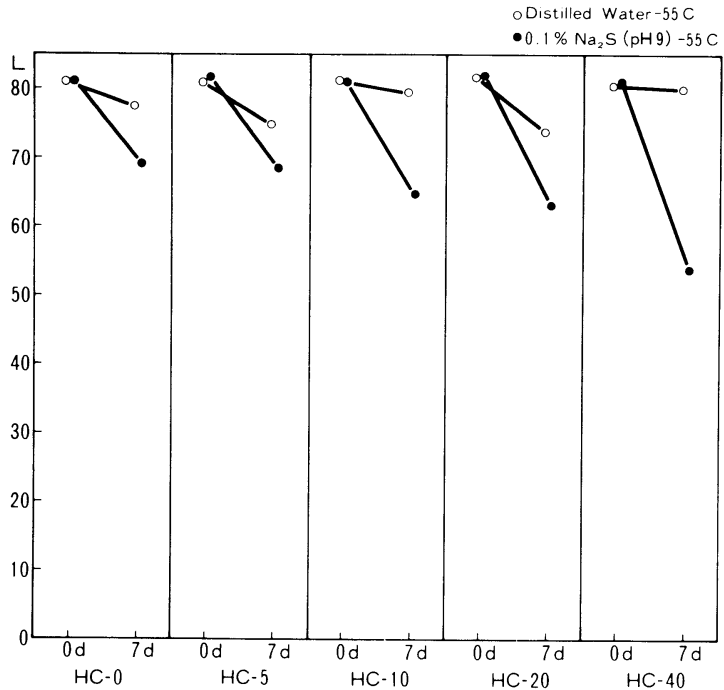

Fig. 16 Discoloration of Experimental Hydrophilic Composite Specimens (HC) Contaminated with Increasing Amounts of $\mathrm{Pb}$ 